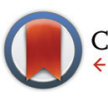

CrossMark click for updates

Cite this: Org. Biomol. Chem., 2015, 13, 4693

Received 16th January 2015 Accepted 12th March 2015

DOI: 10.1039/c5ob00097a www.rsc.org/obc

\title{
Synthesis, conformational studies, and biological properties of phosphonomethoxyethyl derivatives of nucleobases with a locked conformation via a pyrrolidine ring $\dagger$
}

\author{
Radek Pohl, ${ }^{a}$ Lenka Poštová Slavětínská, ${ }^{a}$ Wai Soon Eng, ${ }^{b}$ Dianne T. Keough, ${ }^{b}$ \\ Luke W. Guddat ${ }^{\mathrm{b}}$ and Dominik Rejman ${ }^{\mathrm{a}}$
}

\begin{abstract}
Systematic structure-activity studies on a diverse family of nucleoside phosphonic acids has led to the development of potent antiviral drugs such as HPMPC (CidofovirTM), PMEA (AdefovirTM), and PMPA (TenofovirTM), which are used in the treatment of CMV-induced retinitis, hepatitis $B$, and HIV, respectively. Here, we present the synthesis of a novel class of acyclic phosphonate nucleotides that have a locked conformation via a pyrrolidine ring. NMR analysis of these compounds revealed that the pyrrolidine ring has a constrained conformation when in the cis-form at $\mathrm{pD}<10$ via hydrogen bonding. Four of these compounds were tested as inhibitors of the human and Plasmodium falciparum 6-oxopurine phosphoribosyltransferases. The most potent has a $K_{\mathrm{i}}$ of $0.6 \mu \mathrm{M}$ for Plasmodium falciparum HGXPRT.
\end{abstract}

\section{Introduction}

Over the past few decades, there has been an enormous effort devoted to the synthesis and biochemical and biological evaluation of analogs of natural nucleosides and nucleotides. This has largely been due to their usefulness as tools in investigations aimed at a thorough understanding of metabolic processes. Such analogues exhibit their biological properties either via inhibition of enzymes of the nucleoside/nucleotide metabolism pathway or in the triphosphorylated form, where they can become incorporated into DNA or RNA via the action of polymerases or transcriptases. Among the most successful classes of nucleotide analogs are those which possess the enzymatically and chemically stable phosphonate moiety ${ }^{1}$ as a replacement for the phosphate group. The advantage of this modification is that it improves the stability by preventing hydrolysis of the phosphate ester bond.

Systematic investigation of the structurally diverse nucleoside phosphonic acids has led to the development of potent antiviral drugs. Their chemistry is based on both the acyclic phosphonate nucleotides $\mathbf{1}^{2,3}$ and cyclic counterparts 2 and 3

\footnotetext{
${ }^{a}$ Institute of Organic Chemistry and Biochemistry, Academy of Sciences of the Czech Republic, Flemingovo nám. 2, 16610 Prague 6, Czech Republic.

E-mail: rejman@uochb.cas.cz

${ }^{b}$ The School of Chemistry and Molecular Biosciences, The University of Queensland, Brisbane, 4072 QLD, Australia. E-mail: luke.guddat@uq.edu.au

$\dagger$ Electronic supplementary information (ESI) available. See DOI: 10.1039/ c5ob00097a
}

(Fig. 1). ${ }^{4}$ Specifically, acyclic compounds $\mathbf{1 a - c}$ were shown to inhibit the replication of DNA viruses and retroviruses, whereas cyclic compounds $\mathbf{2 a - d}$ and 3a-d exhibited favorable antiviral profiles against HIV strains. Thus, the modification of the sugar-phosphate moiety of the nucleotides is a successful approach in contributing to the pool of potential antivirals.

Furthermore, several types of aza-sugar nucleoside phosphonates, such as the pyrrolidine $4,{ }^{5,6}$ isoxazolidine $5^{7}$ and $6,{ }^{8}$ and aziridine $7^{9}$ ring-containing compounds, have been reported. However, among these only analogues 6a-e exerted significant inhibition of HIV reverse transcriptase comparable to AZT as well as maintained a low level of cytotoxicity. Pyrrolidine nucleosides $\mathbf{8}$ and $\mathbf{9}^{10}$ served as the starting point for the synthesis of pyrrolidine phosphonate analogs of nucleotides 10a-12, recently described by our group. ${ }^{11}$ Phosphonate derivative $\mathbf{1 3}$ has been found to be a potent inhibitor of thymidine phosphorylase from spontaneous SD-rat lymphoma cells exhibiting an $\mathrm{IC}_{50}$ of $11 \mathrm{nM}^{12}$ and guanine derivative 14 exhibited nanomolar activity against human purine nucleoside phosphorylase. $^{13}$

Herein, we present the synthesis and biological evaluation of phosphonomethoxyethyl derivatives of nucleobases 15a-e and 16a-c (Fig. 2) that are conformationally locked via a pyrrolidine ring. The conformational lock may, in principle, increase the entropy contribution to the binding energy of the ligand to its biological target. Herein we attempted to compare inhibition properties of PMEG and PMEHx with their conformationally locked counterparts $15 \mathbf{b}-\mathbf{c}$ and $\mathbf{1 6 b}-\mathbf{c}$ towards oxopurineribosyltransferases. 

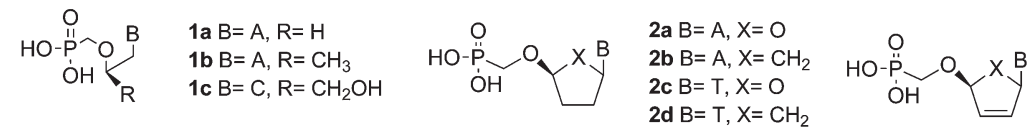

3a $\mathrm{B}=\mathrm{A}, \mathrm{X}=\mathrm{O}$
3b $\mathrm{B}=\mathrm{A}, \mathrm{X}=\mathrm{CH}_{2}$
3c $\mathrm{B}=\mathrm{T}, \mathrm{X}=\mathrm{O}$
3d $\mathrm{B}=\mathrm{T}, \mathrm{X}=\mathrm{CH}_{2}$
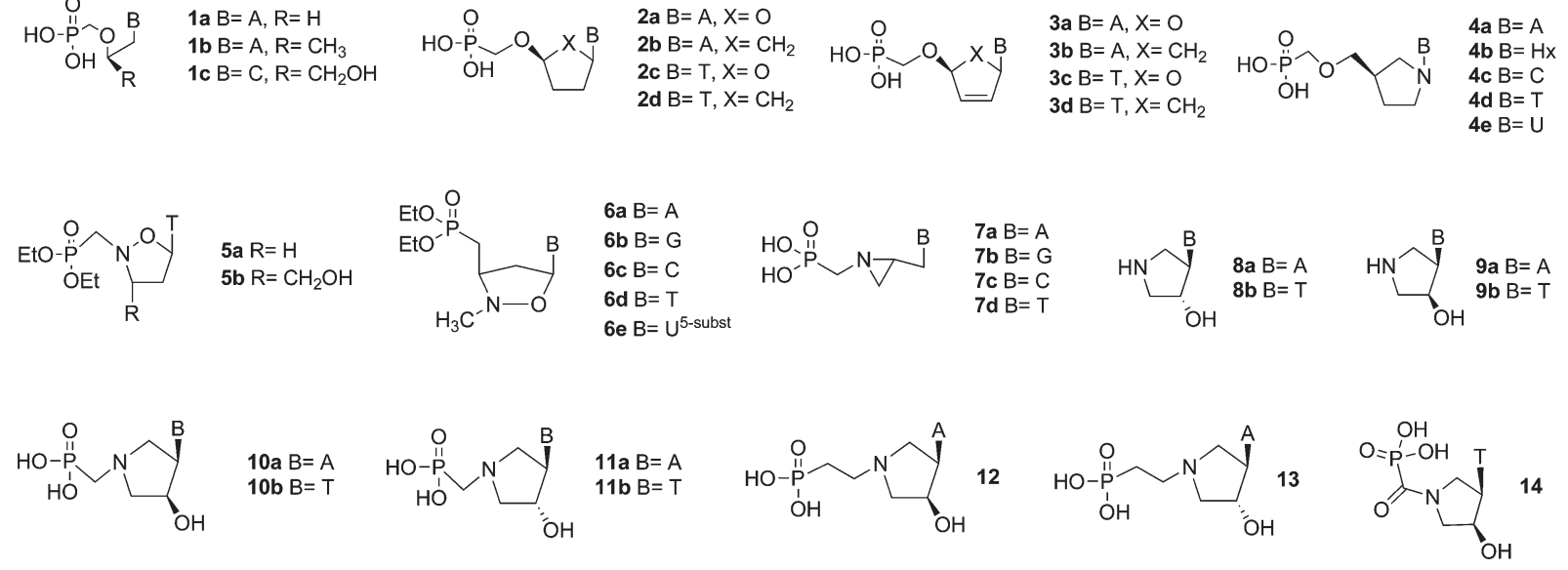

Fig. 1 Structures of nucleotide analogs.
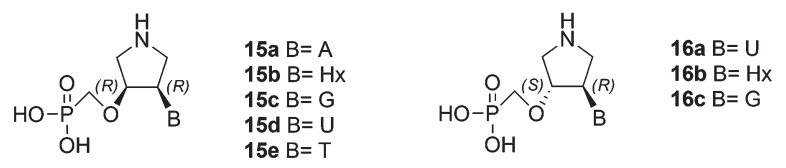

Fig. 2 Structures of target compounds $15 a-e$ and $16 a-c$.

\section{Results and discussion}

\section{Synthesis}

The synthesis of the title compounds could be divided into two parts: (A) synthesis of the pyrrolidine phosphonate intermediate containing either a hydroxyl (19) or primary amino group (23), and (B) attaching the nucleobase to the intermediate (via the Mitsunobu reaction in the case of the hydroxyl derivative or nucleobase assembly procedure on the amino moiety). Two routes to the synthesis of the amino intermediate 23 were evaluated (Scheme 1).

Monodimethoxytrityl derivative $\mathbf{1 7}$ was reacted with diisopropyl tosyloxymethanephosphonate to afford phosphonate $\mathbf{1 8}$ that was treated with $1.5 \%$ TFA in DCM to yield the first intermediate 19. Compound 19 was mesylated and treated with sodium azide giving azido derivative 21 . This reaction was accompanied by removal of one isopropyl ester group decreasing the yield of 21. Thus, a different route to azido derivative 21 was explored. Monodimethoxytrityl derivative 17 was first converted to the azido derivative $\mathbf{2 2}$ that subsequently reacted with diisopropyl tosyloxymethanephosphonate. The obtained azido derivative $\mathbf{2 1}$ was finally converted to the amino derivative 23 by catalytic hydrogenation over a palladium catalyst. The chloropurine intermediate $\mathbf{2 5}$ was prepared by the Mitsunobu reaction of hydroxy derivative 19 with 6-chloropurine (24) (Scheme 2). Adenine derivative 15a was prepared from 25 by aminolysis with conc. aqueous ammonia and dioxane followed by stirring with $20 \%$ TFA in DCM (removal of the Boc protecting group) and finally by bromotrimethylsilane treatment (to remove isopropyl esters). The hypoxanthine derivative $\mathbf{1 5 b}$ was prepared from the same intermediate 25 by bromotrimethylsilane treatment followed by heating with aq. $3 \mathrm{M} \mathrm{HCl}$.

The guanine nucleobase was formed on the amino moiety of 23 using a standard procedure employing 2,5-diamino-4,6dichloropyrimidine (26) according to Scheme $3 .^{14}$

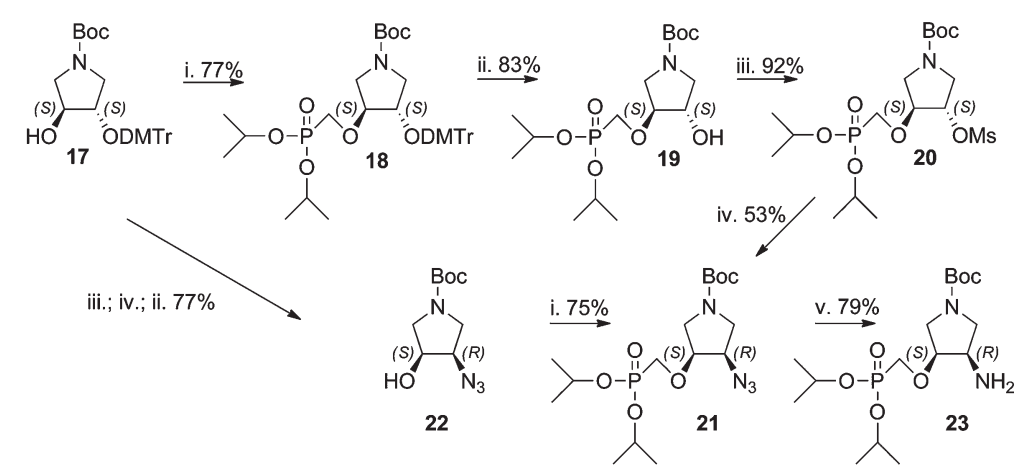

i. $\mathrm{TsOCH}_{2} \mathrm{P}(\mathrm{O})(\mathrm{OiPr})_{2}$, NaH, THF; ii. $1.5 \%$ TFA/DCM; iii. MsCl, DMAP, DCM; iv. $\mathrm{NaN}_{3}$, DMF; v. $\mathrm{H}_{2}, \mathrm{Pd} / \mathrm{C}, \mathrm{EtOH}$

Scheme 1 Synthesis of precursors 19 and 23. 


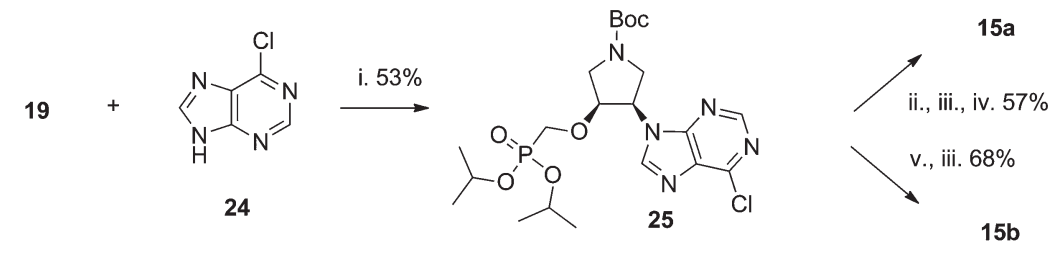

i. $\mathrm{Ph}_{3} \mathrm{P}, \mathrm{DIAD}, \mathrm{THF}$; ii. conc. aq. $\mathrm{NH}_{3}$, dioxane; iii. $\mathrm{Me}_{3} \mathrm{SiBr}, \mathrm{MeCN}$; iv. $20 \%$ TFA/DCM; v. $3 \mathrm{M}$ aq. $\mathrm{HCl}$

Scheme 2 Synthesis of adenine and hypoxanthine derivatives 15a and 15b.

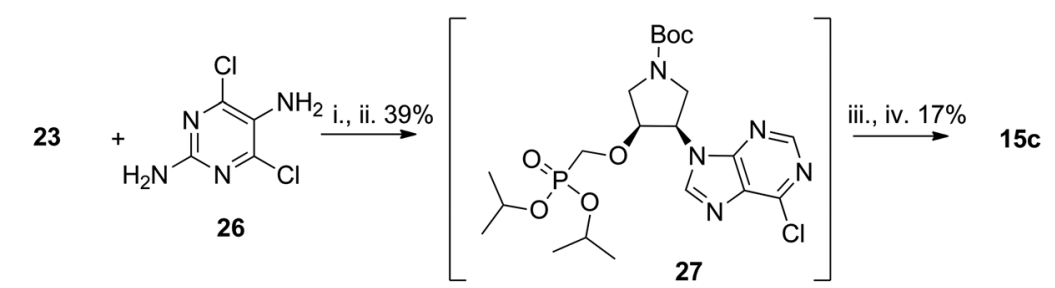

i. DIPEA, nBuOH, $140^{\circ} \mathrm{C}$; ii. (EtO) ${ }_{2} \mathrm{CHOAc}, \mathrm{DMF}$; iii. $\mathrm{Me}_{3} \mathrm{SiBr}, \mathrm{MeCN}$; $1.5 \mathrm{M}$ aq. $\mathrm{HCl}, 80^{\circ} \mathrm{C}$

Scheme 3 Synthesis of guanine derivative 15c.

The reaction of amine $\mathbf{2 3}$ with reagent $28^{15}$ leads to the formation of a linear intermediate with a high yield (Scheme 4). This intermediate, after silica gel chromatography purification,

23

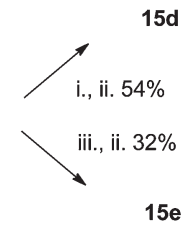

i. 28, dioxane, rt; ii. Dowex 50 , dioxane $80^{\circ} \mathrm{C}$; iii. 29 , dioxane, $r$ was dissolved in dioxane and heated with Dowex 50 in $\mathrm{H}^{+}$for $5 \mathrm{~h}$. The treatment with Dowex accomplished the cyclisation of the uracil moiety, removal of the Boc protecting group and, surprisingly, removal of both isopropyl ester groups, thus leading to the final uracil derivative 15d. The thymine derivative 15e was prepared by the same procedure except that reagent 28 was replaced by reagent $29^{15}$ (Scheme 4).

The uracil derivative 16a with a trans configuration was prepared using the same synthetic procedure as for derivative 15d (Scheme 5). The starting azido derivative $\mathbf{3 0}$ was prepared according to our previously published procedure. ${ }^{13}$ Hypoxanthine derivative $\mathbf{1 6 b}$ and guanine derivative $\mathbf{1 6 c}$ were prepared using the nucleobase assembly approach adopted from ref. 16 (employing 4,6-dichloro-5-formamidopyrimidine (32) and 2-amino-4,6-dichloro-5-formamidopyrimidine (33) respectively) followed by bromotrimethylsilane promoted iso-

Scheme 4 Synthesis of uracil and thymine derivatives $15 \mathrm{~d}$ and $15 \mathrm{e}$.

cectively) followed by bromotrimethylsilane promoted iso- 


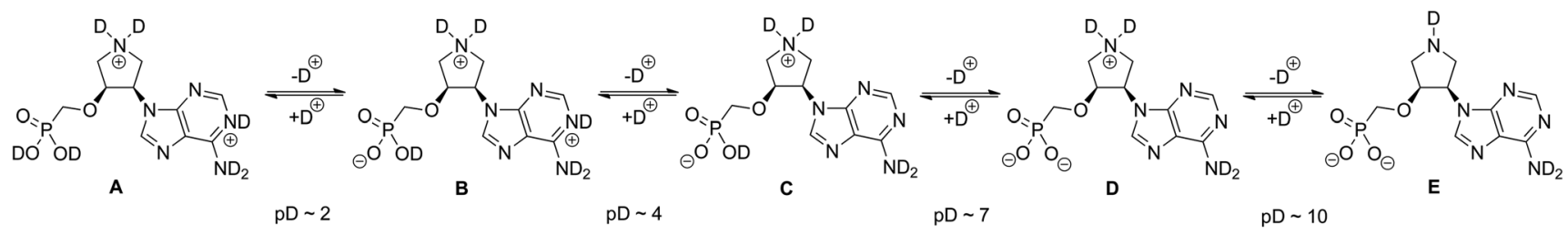

Fig. 3 Deuteration/dedeuteration transitions of $15 a$ in $D_{2} O$ at different $p D$ values.

propyl ester group removal. The reaction of amino derivative 31 with 32 and 33 did not lead to purine ring closure so additional treatment with diethoxymethyl acetate in DMF at elevated temperatures was required. It appears that the nucleobase assembly on a primary amino group is the preferred procedure for introduction of thymine or uracil but for purine bases the Mitsunobu alkylation is the method of choice.

\section{NMR conformational analysis}

The final compounds $\mathbf{1 5 a}-\mathbf{e}$ and $\mathbf{1 6 a}-\mathbf{c}$ were fully characterized by ${ }^{1} \mathrm{H},{ }^{13} \mathrm{C}$ and ${ }^{31} \mathrm{P}$ NMR in $\mathrm{D}_{2} \mathrm{O}$ solutions. The cis and trans relative configuration of uracil derivatives $\mathbf{1 5 d}$ and 16a was determined by inspection of the H,H-ROESY spectrum. Thus, a strong NOE cross-peak of H-6 from the uracil nucleobase and $\mathrm{H}-3^{\prime}$ from the pyrrolidine moiety can be found in the $\mathrm{H}, \mathrm{H}-\mathrm{ROESY}$ spectrum of trans-derivative 16a. This NOE interaction is missing in the case of cis-derivative 15d. In addition, cis and trans isomers differ significantly in the magnitudes of ${ }^{3} J(\mathrm{H}, \mathrm{H})$ coupling constants of pyrrolidine protons. Characteristic values of ${ }^{3} J\left(3^{\prime}, 4^{\prime}\right)$ that can be used for determination of the relative configuration directly from ${ }^{1} \mathrm{H}$ NMR spectra are 4.1-5.3 Hz for cis-derivatives 15a-e and 1.2-2.0 Hz for transderivatives 16a-c.

Since the original acyclic phosphonate moiety in 15a-e and $\mathbf{1 6 a - c}$ is conformationally restricted by the five-membered pyrrolidine ring we were interested in conformation preferences of such pyrrolidine derivatives. Taking into account that molecules contain both acidic (phosphonic acid) and basic (pyrrolidine component) moieties, we first examined at which $\mathrm{pD}$ deuteration/dedeuteration transitions take place (Fig. 3).

Therefore, $\mathrm{D}_{2} \mathrm{O}$ solutions of $\mathbf{1 5 a}$ and $\mathbf{1 6} \mathbf{c}$ were titrated with diluted solutions of $\mathrm{DCl}$ in $\mathrm{D}_{2} \mathrm{O}$ or $\mathrm{NaOD}$ in $\mathrm{D}_{2} \mathrm{O}$ and ${ }^{1} \mathrm{H},{ }^{13} \mathrm{C}$ and ${ }^{31} \mathrm{P}$ NMR spectra were acquired (see ESI $\dagger$ ). Based on the titration curves five different deuterated/dedeuterated forms $\mathrm{A}-\mathrm{E}$ of $15 \mathrm{a}$ can be observed at different $\mathrm{pD}$ values (Fig. 3). The pyrrolidine nitrogen remains in positively charged deuterated form $\mathrm{C}$ until $\mathrm{pD} \sim 10$. This is manifested by the $\mathrm{H}-2^{\prime}$ and $\mathrm{H}-5^{\prime}$ ${ }^{1} \mathrm{H}$ chemical shift changes or $\mathrm{C}-2$ ' and $\mathrm{C}-5,{ }^{13} \mathrm{C}$ chemical shift changes. At $\mathrm{pD} \sim 4$, dedeuteration of adenine nitrogen $\mathrm{N}-1$ was observed by the changes in the ${ }^{13} \mathrm{C}$ chemical shift of C-2 and C-6. We have also found that deuteration/dedeuteration of other derivatives $\mathbf{1 5 b}-\mathbf{e}$ and $\mathbf{1 6} \mathbf{a}-\mathbf{b}$ follows the same trends resulting in dedeuteration of positively charged pyrrolidine nitrogen at $\mathrm{pD} \sim 10$.
The protonation/deprotonation or deuteration/dedeuteration of the pyrrolidine nitrogen can influence the conformation of the five-membered pyrrolidine ring (Fig. 4).

The particular conformation is described by two pseudorotation parameters: by the phase angle $(P)$ and by the maximum puckering amplitude $\left(\phi_{\max }\right){ }^{17}$ The phase angle is a periodic variable indicating which ring atoms are situated outside the ring plane and can reach $0^{\circ}-360^{\circ}$. The maximum puckering amplitude describes the degree of distortion of the five-membered ring out of the plane and its value is usually in the range of $35^{\circ}-45^{\circ}$. Therefore, we examined conformation preferences of the pyrrolidine ring in cis-adenine derivative (15a) and trans-guanine derivative $(\mathbf{1 6 c})$ at low $(<2.0)$ and high $(>12.0) \mathrm{pD}$ values. The conformation analysis based on the concept of pseudorotation ${ }^{17}$ was performed using ${ }^{3} J(\mathrm{H}, \mathrm{H})$ spin-spin couplings of pyrrolidine ring protons within the Matlab Pseudorotation GUI program ${ }^{18}$ and the methodology developed for the conformational analysis of pyrrolidine nucleotide analogues we have published previously. ${ }^{19}$ In transderivative 16c, we observed only negligible changes in ${ }^{3} J(\mathrm{H}, \mathrm{H})$ of pyrrolidine protons upon $\mathrm{pD}$ change indicating little or no change in the conformation of the pyrrolidine ring. This assumption was later confirmed by the conformation analysis

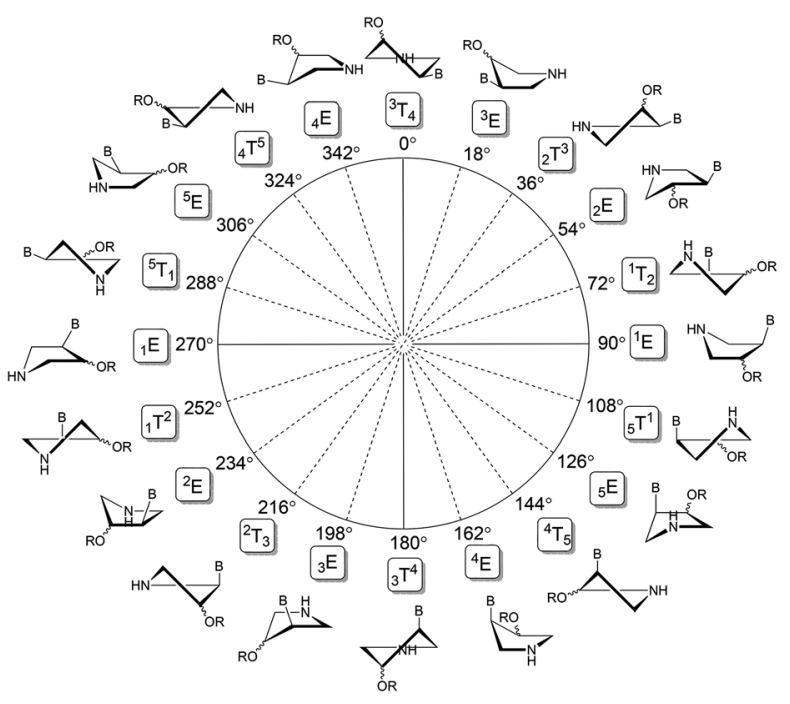

Fig. 4 Pyrrolidine pseudorotation pathway $\left(P=0^{\circ}\right.$ to $\left.360^{\circ}\right)$ of $\mathrm{PME}$ derivatives $15 \mathrm{a}-\mathrm{e}$ and $16 \mathrm{a}-\mathrm{c}$. The sign $\mathrm{B}$ stands for a nucleobase and $\mathrm{R}$ means a phosphonomethyl moiety. 

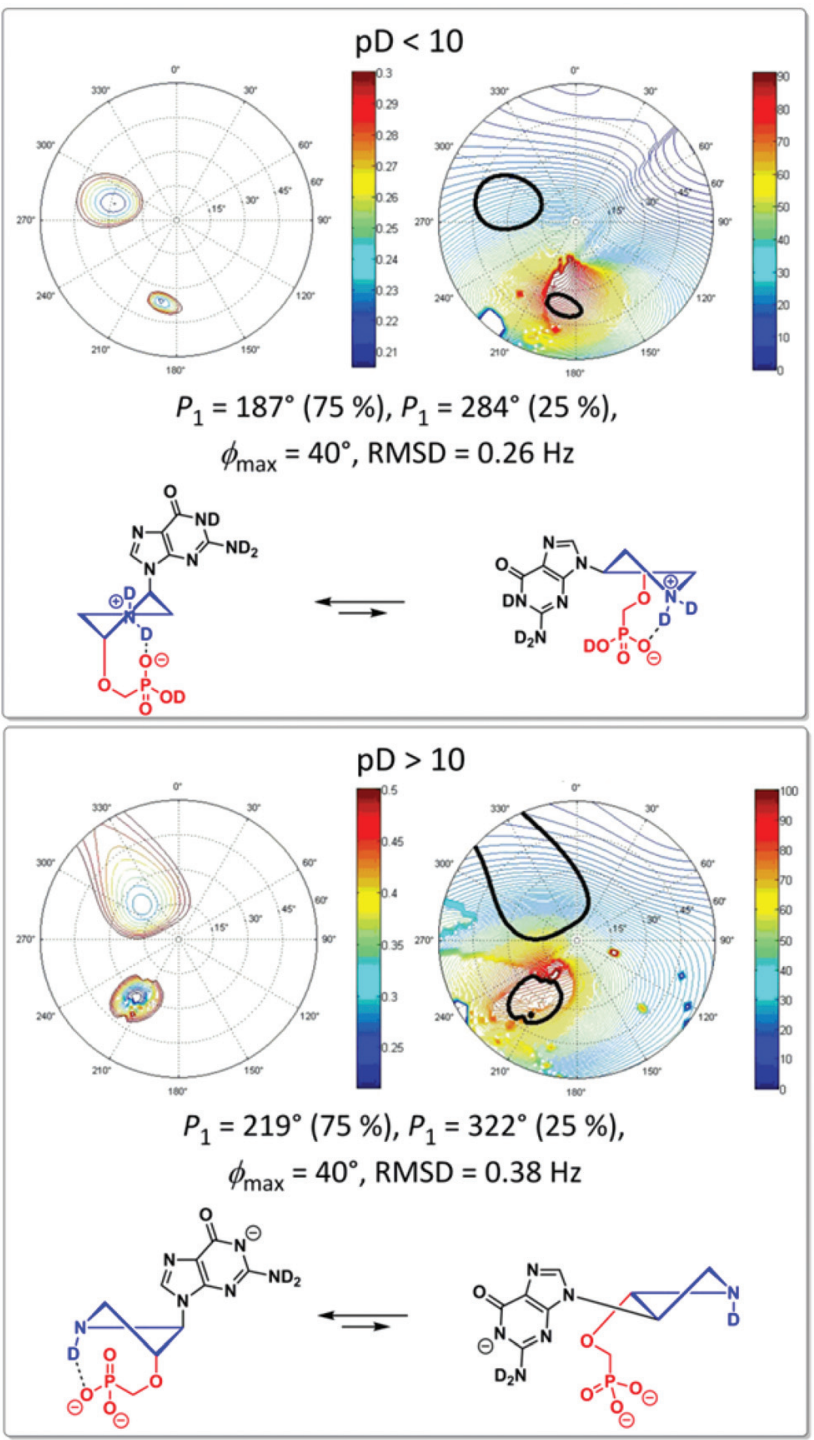

Fig. 5 Conformation of the pyrrolidine ring of derivative $16 \mathrm{c}$ at different $\mathrm{pD}$ values in a $\mathrm{D}_{2} \mathrm{O}$ solution examined by NMR.

of 16c (Fig. 5) that revealed the existence of very similar conformations at both high and low pD.

Changes in ${ }^{3} J(\mathrm{H}, \mathrm{H})$ of pyrrolidine protons of cis-derivative 15a upon pD change (Fig. 6) on the other hand suggest that the dedeuteration of the pyrrolidine ring at $\mathrm{pD} \sim 10$ may result in changes of the pyrrolidine ring conformation.

The conformation analysis of cis-derivative 15a at $\mathrm{pD}<10$ revealed the exclusive existence of one conformer $\left(P=26^{\circ}\right)$ constrained by strong hydrogen bonding between the phosphonate moiety and the deuterated positively charged pyrrolidine nitrogen (Fig. 7). This hydrogen bonding is weakened as a consequence of dedeuteration at $\mathrm{pD}>10$, which results in an equilibrium of two conformers $\left(P_{1}=26^{\circ}(75 \%)\right.$, $\left.P_{2}=253^{\circ}(25 \%)\right)$ in $\mathrm{D}_{2} \mathrm{O}$ solution. Similar behavior was also observed for hypoxanthine and guanine derivatives $\mathbf{1 5 b}$ and 15c, respectively.

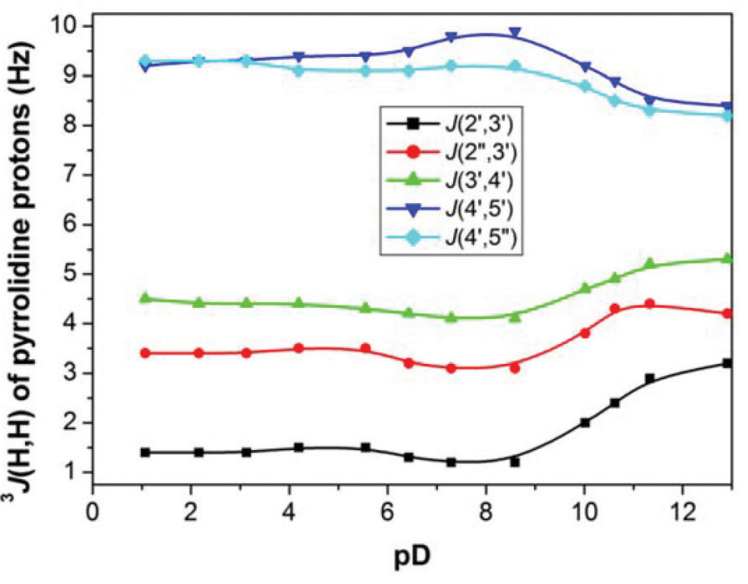

Fig. 6 Changes in the values of ${ }^{3} \mathrm{~J}(\mathrm{H}, \mathrm{H})$ coupling constants of derivative $15 \mathrm{a}$ upon $\mathrm{pD}$ change.
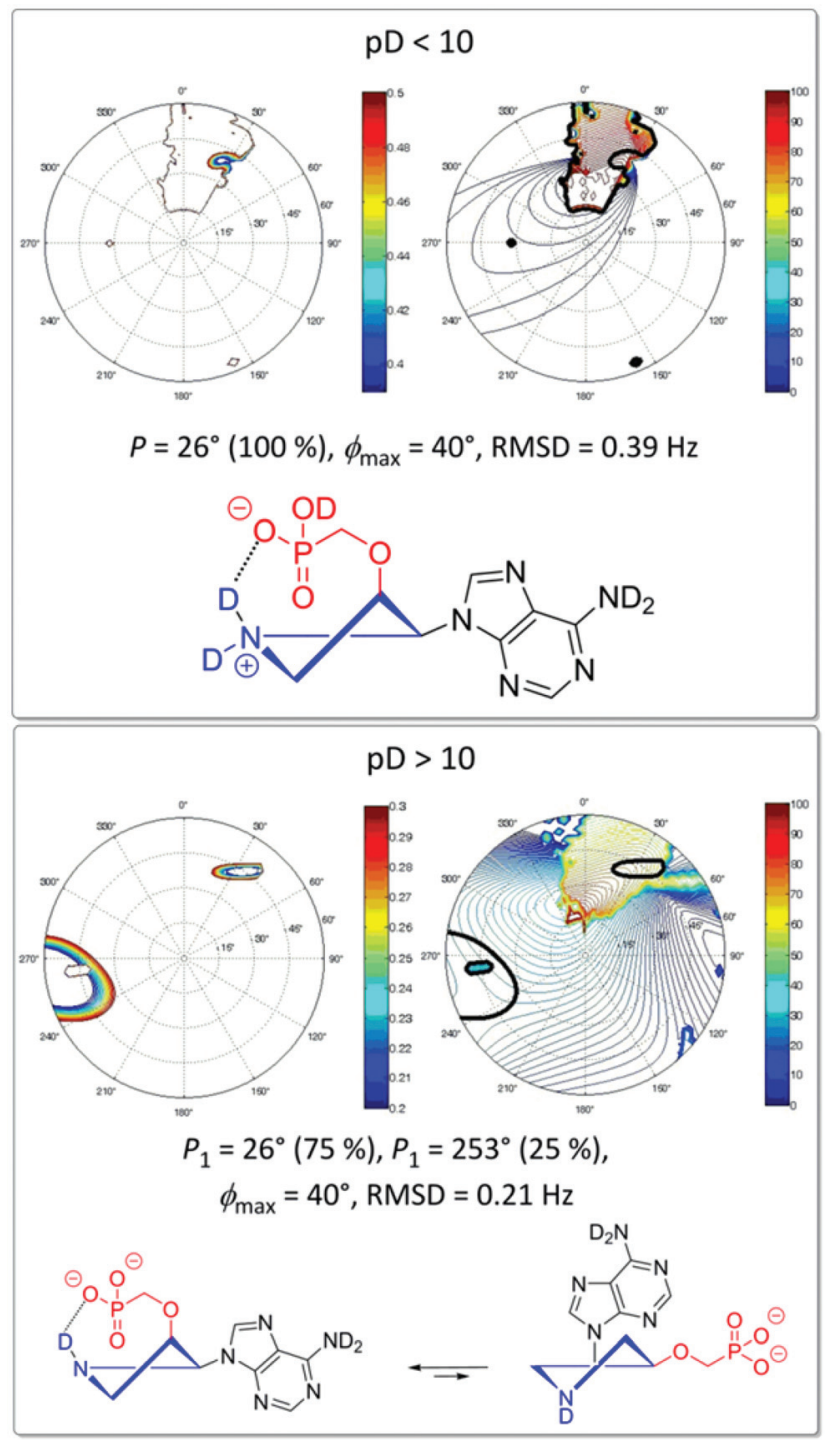

Fig. 7 Conformation of the pyrrolidine ring of derivative 15a at different $\mathrm{pD}$ values in a $\mathrm{D}_{2} \mathrm{O}$ solution examined by NMR. 


\section{Biological activity}

Compounds 15a-e and 16a-c were tested for their cytostatic (HepG2, HL60, HeLa S3, CCRF-CEM), antimicrobial, and antifungal (Escherichia coli CCM 3954, Enterococcus faecalis CCM 4224, Pseudomonas aeruginosa CCM 3955, Staphylococcus aureus CCM 4223, Bacillus subtilis, Streptococcus agalactiae, Candida albicans, and Candida krusei) activities but no significant effects were observed.

Compounds 15a-e and 16a-b did not exhibit any inhibitory activity against human mitochondrial (mdN) and cytosolic (cdN) 5'(3')-deoxynucleotidases. ${ }^{20}$ Compounds 15a and 15e were tested in a HCV replicon assay and did not exhibit any activity at a concentration below $50 \mu \mathrm{M}$.

\section{Inhibition of human HGPRT and PfHGXPRT by pyrrolidine derivatives of PME derivatives of the acyclic nucleoside phosphonates}

The $K_{\mathrm{i}}$ values of four compounds were determined for human hypoxanthine-guanine phosphoribosyltransferase (HGPRT) and $P$. falciparum $(P f)$ hypoxanthine-guanine-xanthine phosphoribosyltransferase (HGXPRT) - a potential drug target for treatment of malaria (Table 1). There are two chemical differences between these compounds: (i) the purine base is either guanine or hypoxanthine; and (ii) there are two isomers. One has the $S$ configuration at the carbon atom of the five membered ring and the second has the $R$ configuration.

The data show that compounds as the $S$-isomer have lower $K_{\mathrm{i}}$ values for the parasite enzyme while those that are the $R$-isomer have lower $K_{\mathrm{i}}$ values for the human enzyme. The inhibitors containing hypoxanthine (15b vs. 15c and 16b vs. 16c) as the base have lower $K_{\mathrm{i}}$ values for the parasite enzyme but the reverse is true for the human enzyme as it favours compounds with guanine as the base.

\section{Structural analysis}

Docking studies were undertaken to try to understand how the pyrrolidine derivatives bind in the active site. ${ }^{22}$ The crystal structures of human HGPRT in complex with 9-2-[-2(phosphonoethoxy)ethyl]guanine (PEEG) and 9-2-[-2(phosphonoethoxy)ethyl]hypoxanthine (PEEHx) (PDB: 3GGC and 3GGJ, respectively) were used as the model template. ${ }^{21}$ The PEE compounds contain an extra carbon atom in the linker connecting the $\mathrm{N}^{9}$

Table $1 \mathrm{HG}(\mathrm{X}) \mathrm{PRT}$ inhibitory activity of compounds 15b, 15c, 16b, and $16 \mathrm{c}$

\begin{tabular}{lcc}
\hline & \multicolumn{1}{c}{$K_{\mathrm{i}}(\mu \mathrm{M})$} & \\
\cline { 2 - 3 } Compound & $\mathrm{Hu}$ & $P f$ \\
\hline $\mathbf{1 5 b}$ & 72 & 0.6 \\
$\mathbf{1 5 c}$ & 29 & 2 \\
$\mathbf{1 6 b}$ & 5.7 & 80 \\
$\mathbf{1 6 c}$ & 0.3 & $\mathrm{NI}$ \\
PMEG $^{21}$ & 29 & 1.6 \\
PEEG $^{21}$ & 1.0 & 0.1 \\
PEEHx $^{21}$ & 3.6 & 0.3
\end{tabular}

atom of the purine ring with the phosphorus atom of the phosphonate group compared with 15b, 15c, 16b and 16c. However, they are similar in that they both contain an oxygen atom two atoms distal to the $\mathrm{N}^{9}$. The acyclic nucleoside phosphonates (PEEG and PEEHx) bind to two key regions in the active site of human HGPRT: the purine binding site and the $5^{\prime}$-phosphate binding pocket (D137-T141). ${ }^{21}$ To validate this approach, we first docked PEEG and PEEHx into the protein devoid of the ligand. The results showed that all the highest scoring docking poses correlated with the position observed in the crystal structure. The rmsd for all atoms in the ligands was $<0.2 \AA$ (Fig. 8a and b). The docked structures of $\mathbf{1 5 b}$ and $\mathbf{1 6 b}$ are compared in Fig. $8 \mathrm{c}$ and those of $15 \mathrm{c}$ and $16 \mathrm{c}$ are compared in Fig. 8d.

These data show that the phosphonate group in all four compounds is found in the 5 '-phosphate binding pocket, but it can have two different orientations depending on the isomer. Thus, the chemical structure of the two isomers appears to be responsible for the location of the phosphonate group. Therefore, the nature of the base itself does not affect the location of the phosphonate group ( $c f$. 15b with 15c and 16b with 16c). The differences in affinity for each isomer with either guanine or $\mathrm{Hx}$ as the base only relates to the binding of the base itself as human HGPRT has a higher affinity for guanine over hypoxanthine but PfHGXPRT binds hypoxanthine better than guanine. ${ }^{23}$ For the weaker inhibitors of human HGPRT (15b and 15c), the phosphonate group does

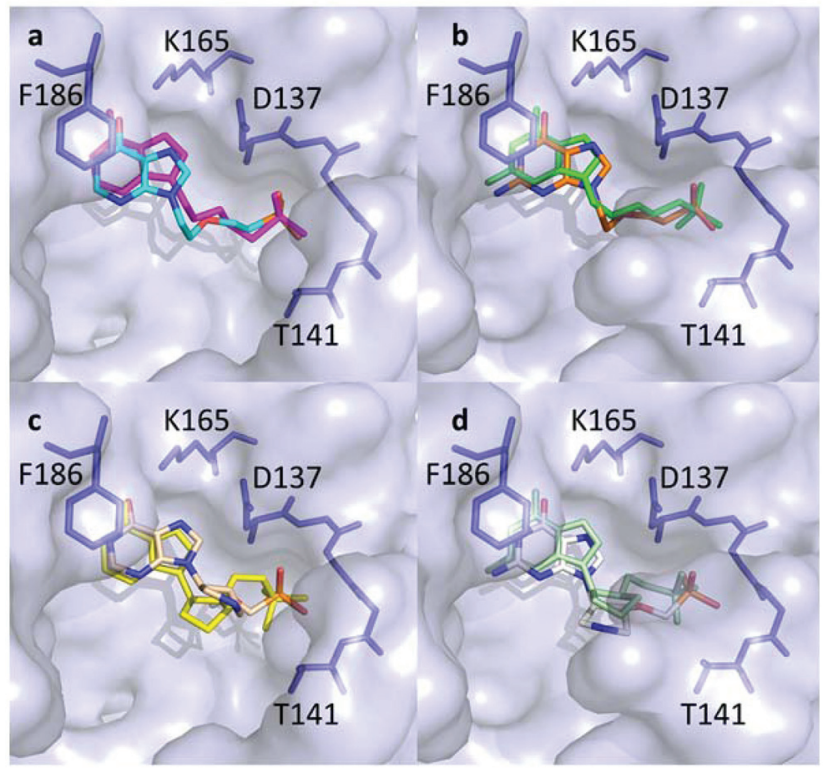

Fig. 8 Molecular docking models and the crystal structure of the nucleoside phosphonates in the active site of human HGPRT. (a) Comparison of the location of PEEHx in the crystal structure (carbon atoms in cyan) with that of the docked compound (magenta). (b) Comparison of the location of PEEG in the crystal structure (carbon atoms in tan) with that of the docked compound (bright green). (c) 15b (yellow) and 16b (carbon atoms in cream). (d) 15c (pale green) and 16c (carbon atoms in white). 
not reach as far into the $5^{\prime}$-phosphate binding pocket as it does in 16b and 16c. This location of the phosphonate group in the active site could be one of the contributing factors for the differences in the $K_{\mathrm{i}}$ values between the human and $P f$ enzymes for the two isomers. In comparison, PfHGXPRT favours the $S$-isomers of the pyrrolidine nucleoside phosphonates over their $R$-isomer counterparts. The docking studies suggest that the "open" structure of these pyrrolidine derivatives is preferred to the "locked" structure when these compounds bind in the active site of the 6-oxopurine phosphoribosyltransferases.

\section{Conclusions}

Eight PME derivatives of nucleobases with a locked conformation via a pyrrolidine ring have been synthesized. Pyrimidine derivatives were prepared in good yields via nucleobase construction on a primary amine. In the case of purine bases, Mitsunobu coupling with a hydroxy derivative appeared to be a better approach than construction of the nucleobase on a primary amino group. NMR conformation analysis revealed that the conformation of the pyrrolidine ring in cis-series 15 is $\mathrm{pH}$ dependent. It was found that protonation of the pyrrolidine ring at $\mathrm{pH}<10$ is responsible for the constraining of the conformation and the exclusive existence of one conformer. Derivatives bearing hypoxanthine and guanine nucleobases were tested as inhibitors of the human and Plasmodium falciparum 6-oxopurine phosphoribosyltransferases. The most potent compound $\mathbf{1 5 b}$ has a $K_{\mathrm{i}}$ of $0.6 \mu \mathrm{M}$ for $P f$ HGXPRT with the selectivity in favour of the $P f$ enzyme over its human counterpart of approx. 120-fold ( $S$-isomer). However, when the purine base is the same but the isomer is different ( $R$-isomer), this selectivity changes in favour of the human enzyme (14fold in favour of the human enzyme). Docking studies suggest that the $R$-isomer is favoured for the human HGPRT because the phosphonate group reaches further into the 5 '-phosphate binding pocket. This allows the phosphoryl oxygens to form more hydrogen bonds with the amino acid side chain or main chain atoms in the flexible loop surrounding this group. These findings will help us in designing better and more selective inhibitors of parasite HGXPRT.

\section{Experimental}

Unless stated otherwise, all used solvents were anhydrous. The final products were lyophilized from water, and dried over phosphorus pentoxide at $50-70{ }^{\circ} \mathrm{C}$ and $13 \mathrm{~Pa}$. TLC was performed on silica gel pre-coated aluminium plates silica gel/ TLC-cards, UV 254 (Fluka), and compounds were detected with UV light (254 nm), by heating (detection of the dimethoxytrityl group; orange color), by spraying with a $1 \%$ solution of ninhydrin to visualize amines, and by spraying with a $1 \%$ solution of 4-(4-nitrobenzyl)pyridine in ethanol followed by heating and treating with gaseous ammonia (blue color of mono- and di- esters of phosphonic acid). Preparative column chromatography was carried out on silica gel $(40-60 \mu \mathrm{m}$; Fluka) neutralized with triethylamine $\left(1 \mathrm{ml} 100 \mathrm{~g}^{-1}\right)$, and elution was

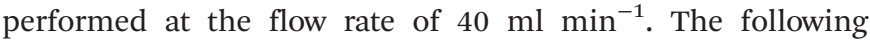
solvent systems were used for TLC and preparative chromatography: toluene-ethyl acetate 1:1 (T); chloroform-ethanol 9:1 (C1); ethyl acetate-acetone-ethanol-water 6:1:1:0.5 (H3); ethyl acetate-acetone-ethanol-water $4: 1: 1: 1$ (H1). The concentrations of solvent systems are stated as volume percentages $(\%, v / v)$. Analytical RP HPLC was performed on an LC5000 Liquid Chromatograph (INGOS-PIKRON, CR) using a Luna C18 (2) column $(4.6 \times 150 \mathrm{~mm})$ at a flow rate of $1 \mathrm{ml}$ $\min ^{-1}$ by gradient elution of methanol in $0.1 \mathrm{M}$ TEAA $\mathrm{pH} 7.5$ ( $A=0.1 \mathrm{M}$ TEAA; $B=0.1 \mathrm{M}$ TEAA in $50 \%$ aqueous methanol; $C$ = methanol). Mass spectra were recorded on a ZAB-EQ (VG Analytical) instrument, using FAB (ionization with Xe, accelerating voltage $8 \mathrm{kV}$ ). Glycerol and thioglycerol were used as matrices. NMR spectra were measured on Bruker AVANCE 600 $\left({ }^{1} \mathrm{H}\right.$ at $600.1 \mathrm{MHz},{ }^{13} \mathrm{C}$ at $\left.150.9 \mathrm{MHz}\right)$, Bruker AVANCE 500 and Varian UNITY $500\left({ }^{1} \mathrm{H}\right.$ at 500.0 and $499.8 \mathrm{MHz},{ }^{13} \mathrm{C}$ at 125.7 MHz, ${ }^{31} \mathrm{P}$ at $202.3 \mathrm{MHz}$ ) spectrometers. Chemical shifts (in ppm, $\delta$ scale) were referenced to the solvent signal $\left(\mathrm{CDCl}_{3}\right.$, ${ }^{1} \mathrm{H}: 7.26 \mathrm{ppm},{ }^{13} \mathrm{C}$ : 77.0 ppm; DMSO- $d_{6},{ }^{1} \mathrm{H}: 2.50 \mathrm{ppm},{ }^{13} \mathrm{C}$ $39.7 \mathrm{ppm}$ ), or to dioxane as the external standard when $\mathrm{D}_{2} \mathrm{O}$ solutions were used $\left({ }^{1} \mathrm{H}: 3.75 \mathrm{ppm},{ }^{13} \mathrm{C}: 69.3 \mathrm{ppm}\right)$. Coupling constants $(J)$ are given in Hz. Complete assignment of protons and carbons was done by analysis of correlated homonuclear 2D-COSY and heteronuclear ${ }^{1} \mathrm{H}^{-13} \mathrm{C}$ HSQC and ${ }^{1} \mathrm{H}^{-13} \mathrm{C} \mathrm{HMBC}$ spectra. The relative configuration was checked using DPFGSENOE and 2D-ROESY techniques.

\section{[3S,4R]-(4-(Adenin-9-yl)pyrrolidin-3-yl)oxymethanephosphonic acid 15a}

A mixture of $25(0.72 \mathrm{~g}, 1.38 \mathrm{mmol})$, dioxane $(14 \mathrm{ml})$ and conc. aq. ammonia $(50 \mathrm{ml})$ was stirred at $50{ }^{\circ} \mathrm{C}$ in a sealed flask for five days. The mixture was concentrated in vacuo. The protected adenine intermediate (HRMS $\left(\mathrm{FAB}+\right.$ ) for $\mathrm{C}_{21} \mathrm{H}_{36} \mathrm{~N}_{6} \mathrm{O}_{6} \mathrm{P}$ $(\mathrm{M}+\mathrm{H})^{+}$calcd 499.2428 , found 499.2429$)$ was obtained by column chromatography on silica gel using a linear gradient of ethanol in chloroform.

This intermediate $(0.69 \mathrm{~g}, 1.384 \mathrm{mmol})$ was without further characterisation dissolved in $20 \%$ TFA in DCM $(20 \mathrm{ml})$. The reaction mixture was stirred at $\mathrm{rt}$ overnight. The reaction mixture was diluted with chloroform $(50 \mathrm{ml})$ and extracted with water $(2 \times 50 \mathrm{ml})$. The aqueous phase was applied to a column of Dowex 50 in $\mathrm{H}^{+}$form. Dowex was washed with water $(200 \mathrm{ml})$ and eluted with $3 \%$ aq. ammonia. The yellowish solution was evaporated. The residue was co-evaporated with ethanol $(1 \times 20 \mathrm{ml})$ and acetonitrile $(2 \times 20 \mathrm{ml})$ and dissolved in DMF $(15 \mathrm{ml})$. Bromotrimethylsilane $(1 \mathrm{ml}, 7 \mathrm{mmol})$ was added under an argon atmosphere and the reaction mixture was stirred at rt for two days. The reaction mixture was concentrated in vacuo. $2 \mathrm{M}$ aq. TEAB $(5 \mathrm{ml})$ and ethanol $(10 \mathrm{ml})$ were added. The solution was concentrated in vacuo. The title compound was obtained by preparative HPLC on the reversed phase using a linear gradient of methanol in $0.1 \mathrm{M}$ aq. TEAB. 
After conversion to sodium salt by passing through a column of Dowex 50 in $\mathrm{Na}^{+}$form $(30 \mathrm{ml})$ the title compound was obtained in $58 \%(0.27 \mathrm{~g}, 0.803 \mathrm{mmol})$ yield as a fluffy solid (after lyophilisation from water).

${ }^{1} \mathrm{H}$ NMR (499.8 MHz, $\left.\mathrm{D}_{2} \mathrm{O}, 25{ }^{\circ} \mathrm{C}\right): 3.35\left(\mathrm{dd}, 1 \mathrm{H}, J_{\text {gem }}=12.1\right.$, $\left.J_{\mathrm{H}, \mathrm{P}}=8.2, \mathrm{CH}_{\mathrm{a}} \mathrm{H}_{\mathrm{b}} \mathrm{P}\right) ; 3.48\left(\mathrm{dd}, 1 \mathrm{H}, J_{\text {gem }}=12.1, J_{\mathrm{H}, \mathrm{P}}=10.3\right.$, $\mathrm{CH}_{\mathbf{a}} \mathrm{H}_{\mathrm{b}} \mathrm{P}$ ); $3.54\left(\mathrm{dd}, 1 \mathrm{H}, J_{\text {gem }}=12.9, J_{2^{\prime} \mathrm{b}, 3^{\prime}}=3.0, \mathrm{H}-2^{\prime} \mathrm{b}\right) ; 3.80$ (dd, $\left.1 \mathrm{H}, J_{\text {gem }}=12.0, J_{5^{\prime} \mathrm{b}, 4^{\prime}}=9.7, \mathrm{H}-5^{\prime} \mathrm{b}\right) ; 3.86\left(\mathrm{dd}, 1 \mathrm{H}, J_{\text {gem }}=12.9\right.$, $\left.J_{2^{\prime} \mathrm{a}, 3^{\prime}}=1.2, \mathrm{H}-2^{\prime} \mathrm{a}\right) ; 3.91\left(\mathrm{dd}, 1 \mathrm{H}, J_{\text {gem }}=12.0, J_{5^{\prime} \mathrm{a}, 4^{\prime}}=9.1, \mathrm{H}-5^{\prime} \mathrm{a}\right)$; 4.43 (ddd, $\left.1 \mathrm{H}, J_{3^{\prime}, 4^{\prime}}=4.1, J_{3^{\prime}, 2^{\prime}}=3.0,1.2, \mathrm{H}-3^{\prime}\right) ; 5.37(\mathrm{ddd}, 1 \mathrm{H}$, $\left.J_{4^{\prime}, 5^{\prime}}=9.7,9.1, J_{4^{\prime}, 3^{\prime}}=4.1, \mathrm{H}^{-} 4^{\prime}\right) ; 8.21(\mathrm{~s}, 1 \mathrm{H}, \mathrm{H}-2) ; 8.58(\mathrm{~s}, 1 \mathrm{H}$, $\mathrm{H}-8)$.

${ }^{13} \mathrm{C}$ NMR (125.7 MHz, D $\left.2 \mathrm{O}, 25{ }^{\circ} \mathrm{C}\right): 48.39\left(\mathrm{CH}_{2}-5^{\prime}\right) ; 51.32$ $\left(\mathrm{CH}_{2}-2^{\prime}\right) ; 57.10\left(\mathrm{CH}-4^{\prime}\right) ; 69.95\left(\mathrm{~d}, J_{\mathrm{C}, \mathrm{P}}=150.7, \mathrm{CH}_{2} \mathrm{P}\right) ; 80.73(\mathrm{~d}$, $\left.J_{\mathrm{C}, \mathrm{P}}=12.1, \mathrm{CH}-3^{\prime}\right) ; 120.57(\mathrm{C}-5) ; 144.96(\mathrm{CH}-8) ; 152.08(\mathrm{C}-4)$; 155.29 (CH-2); 158.27 (C-6).

${ }^{31} \mathrm{P}\left\{{ }^{1} \mathrm{H}\right\}$ NMR $\left(202.3 \mathrm{MHz}, \mathrm{D}_{2} \mathrm{O}, 25^{\circ} \mathrm{C}\right): 12.86$.

IR $\nu_{\max }(\mathrm{KBr}) 2370(\mathrm{w}, \mathrm{vbr}), 1644$ (s), 1605 (s), $1576(\mathrm{~m})$, 1509 (w), 1477 (m), 1418 (w), 1374 (w), 1333 (w), 1301 (w), 1254 (w), 1224 (vw), 1115 (m, br, sh), 1075 (m, br), 970 (m), 798 (w), $648(\mathrm{w})$.

HRMS (ESI+) for $\mathrm{C}_{10} \mathrm{H}_{16} \mathrm{~N}_{6} \mathrm{O}_{4} \mathrm{P}(\mathrm{M}+\mathrm{H})^{+}$: calcd 315.09652, found 315.09648.

$[\alpha]^{20}=+43.2\left(c 0.389, \mathrm{H}_{2} \mathrm{O}\right)$.

\section{[3S,4R]-(4-(Hypoxanthin-9-yl)pyrrolidin-3-yl)- oxymethanephosphonic acid 15b}

Bromotrimethylsilane $(0.66 \mathrm{ml}, 5 \mathrm{mmol})$ was added to a solution of compound $25(0.54 \mathrm{~g}, 1.04 \mathrm{mmol})$ in acetonitrile $(10 \mathrm{ml})$ under an argon atmosphere. The reaction mixture was stirred at rt overnight. The reaction mixture was concentrated in vacuo, co-evaporated with toluene $(2 \times 10 \mathrm{ml})$ and dissolved in $3 \mathrm{M}$ aq. $\mathrm{HCl}(30 \mathrm{ml})$. The mixture was stirred at $80^{\circ} \mathrm{C}$ overnight, diluted with water $(100 \mathrm{ml})$ and applied on a column of Dowex 50 in $\mathrm{H}^{+}$form $(100 \mathrm{ml})$. The resin was washed with water $(150 \mathrm{ml})$ and the crude product was eluted with $3 \% \mathrm{aq}$. ammonia. The title compound was obtained in pure form by preparative HPLC, and converted to sodium salt by passing through a column of Dowex 50 in $\mathrm{Na}^{+}$form. After lyophilisation from water $68 \%$ yield $(0.24 \mathrm{~g}, 0.71 \mathrm{mmol})$ of the title compound was obtained in the form of a white amorphous solid.

${ }^{1} \mathrm{H}$ NMR (600.1 MHz, $\left.\mathrm{D}_{2} \mathrm{O}, 25{ }^{\circ} \mathrm{C}\right): 3.05\left(\mathrm{dd}, 1 \mathrm{H}, J_{\text {gem }}=12.5\right.$, $\left.J_{\mathrm{H}, \mathrm{P}}=8.3, \mathrm{CH}_{\mathrm{a}} \mathrm{H}_{\mathrm{b}} \mathrm{P}\right) ; 3.25\left(\mathrm{dd}, 1 \mathrm{H}, J_{\text {gem }}=12.5, J_{\mathrm{H}, \mathrm{P}}=9.6\right.$, $\left.\mathrm{CH}_{\mathrm{a}} \mathrm{H}_{\mathrm{b}} \mathrm{P}\right) ; 3.26\left(\mathrm{~d}, 2 \mathrm{H}, J_{2^{\prime}, 3^{\prime}}=3.8, \mathrm{H}-2^{\prime}\right) ; 3.30\left(\mathrm{dd}, 1 \mathrm{H}, J_{\text {gem }}=\right.$ $\left.11.8, J_{5^{\prime} \mathrm{b}, 4^{\prime}}=8.7, \mathrm{H}-5^{\prime} \mathrm{b}\right) ; 3.45\left(\mathrm{dd}, 1 \mathrm{H}, J_{\text {gem }}=11.8, J_{5^{\prime} \mathrm{a}, 4^{\prime}}=8.2\right.$, $\left.\mathrm{H}-5^{\prime} \mathrm{a}\right) ; 4.27$ (dt, $\left.1 \mathrm{H}, J_{3^{\prime}, 4^{\prime}}=5.3, J_{3^{\prime}, 2^{\prime}}=3.8, \mathrm{H}-3^{\prime}\right)$; 5.06 (ddd, $1 \mathrm{H}$, $\left.J_{4^{\prime}, 5^{\prime}}=8.7,8.2, J_{4^{\prime}, 3^{\prime}}=5.3, \mathrm{H}-4^{\prime}\right) ; 8.15$ (s, $\left.1 \mathrm{H}, \mathrm{H}-2\right)$; 8.30 (s, $\left.1 \mathrm{H}, \mathrm{H}-8\right)$.

${ }^{13} \mathrm{C}$ NMR (150.9 MHz, $\left.\mathrm{D}_{2} \mathrm{O}, 25{ }^{\circ} \mathrm{C}\right): 51.09\left(\mathrm{CH}_{2}-5^{\prime}\right) ; 52.68$ $\left(\mathrm{CH}_{2}-2^{\prime}\right) ; 58.65\left(\mathrm{CH}-4^{\prime}\right) ; 70.37\left(\mathrm{~d}, J_{\mathrm{C}, \mathrm{P}}=151.1, \mathrm{CH}_{2} \mathrm{P}\right) ; 82.60(\mathrm{~d}$, $\left.J_{\mathrm{C}, \mathrm{P}}=10.5, \mathrm{CH}-3^{\prime}\right) ; 125.17$ (C-5); 143.35 (CH-8); 152.93 (C-4); $155.86(\mathrm{CH}-2) ; 170.01$ (C-6).

${ }^{31} \mathrm{P}\left\{{ }^{1} \mathrm{H}\right\}$ NMR $\left(202.3 \mathrm{MHz}, \mathrm{D}_{2} \mathrm{O}, 25^{\circ} \mathrm{C}\right): 13.60$.

IR $\nu_{\max }(\mathrm{KBr}) 3415$ (vs, br), 32609 (vs, vbr, sh), 3137 (vs, vbr), 1685 (s), 1559 (s), 1520 (m), 1470 (s), 1415 (m, sh), 1383 (m), 1335 (m), 1119 (s, br), 1051 (m, sh), 912 (w, sh), 896 (w, sh), $793(\mathrm{vw}), 652(\mathrm{~m})$.
HRMS (ESI-) for $\mathrm{C}_{10} \mathrm{H}_{13} \mathrm{~N}_{5} \mathrm{O}_{5} \mathrm{P}(\mathrm{M}-\mathrm{H})^{-}$: calcd 314.06598, found 314.06611.

$$
[\alpha]^{20}=+19.6\left(c 0.73, \mathrm{H}_{2} \mathrm{O}\right) \text {. }
$$

[3S,4R]-(4-(Guanin-9-yl)pyrrolidin-3-yl)oxymethanephosphonic acid 15c

A mixture of amino derivative 23 (1.95 g, $5.13 \mathrm{mmol}$ ), 2,5diamino-4,6-dichloropyrimidine (1.8 g, $10.26 \mathrm{mmol})$ and TEA (3 $\mathrm{ml}, 22 \mathrm{mmol})$ in $n \mathrm{BuOH}(50 \mathrm{ml})$ was stirred in a sealed reactor at $150{ }^{\circ} \mathrm{C}$ overnight. The pyrimidine intermediate was obtained by chromatography on silica gel using a linear gradient of ethanol in chloroform (66\% yield, $1.77 \mathrm{~g}, 3.37 \mathrm{mmol}$ ), dissolved in diethoxymethylacetate $(20 \mathrm{ml})$ and stirred at rt for $20 \mathrm{~h}$. The reaction mixture was stirred at $80{ }^{\circ} \mathrm{C}$ for an additional $2 \mathrm{~h}$ and at $110{ }^{\circ} \mathrm{C}$ overnight. Chloroaminopurine intermediate 27 was obtained by column chromatography on silica gel using a linear gradient of ethanol in chloroform in $39 \%$ yield $(0.77 \mathrm{~g}, 1.33 \mathrm{mmol})$ in the form of a gray amorphous solid and used without further characterisation.

TMSBr $(0.88 \mathrm{ml}, 6.65 \mathrm{mmol})$ was added to a solution of the intermediate 27 in DMF (15 ml) at rt under an argon atmosphere. The reaction mixture was stirred overnight. The mixture was concentrated in vacuo. The residue was dissolved in $1.5 \mathrm{M}$ aq. $\mathrm{HCl}(50 \mathrm{ml})$ and stirred at $80{ }^{\circ} \mathrm{C}$ overnight. The reaction mixture was diluted with water $(100 \mathrm{ml})$ and applied on a column of Dowex 50 in $\mathrm{H}^{+}$form $(80 \mathrm{ml})$. The Dowex was washed with water $(150 \mathrm{ml})$ and the crude product was eluted with $3 \%$ aq. ammonia. The solvent was removed in vacuo and the title compound was obtained using preparative reversed phase HPLC, converted to its sodium salt by passing through a column of Dowex 50 in $\mathrm{Na}^{+}$form and lyophilized from water in $17 \%$ overall yield ( $81 \mathrm{mg}, 0.23 \mathrm{mmol}$ ) in the form of a white amorphous solid.

${ }^{1} \mathrm{H}$ NMR (499.8 MHz, $\left.\mathrm{D}_{2} \mathrm{O}, 25^{\circ} \mathrm{C}\right): 3.20\left(\mathrm{dd}, 1 \mathrm{H}, J_{\text {gem }}=12.6\right.$, $\left.J_{\mathrm{H}, \mathrm{P}}=8.2, \mathrm{CH}_{\mathrm{a}} \mathrm{H}_{\mathrm{b}} \mathrm{P}\right) ; 3.29\left(\mathrm{dd}, 1 \mathrm{H}, J_{\text {gem }}=12.9, J_{2^{\prime} \mathrm{b}, 3^{\prime}}=4.4, \mathrm{H}-2^{\prime}\right.$ b); $3.33\left(\mathrm{dd}, 1 \mathrm{H}, J_{\text {gem }}=12.6, J_{\mathrm{H}, \mathrm{P}}=9.3, \mathrm{CH}_{\mathrm{a}} \mathrm{H}_{\mathrm{b}} \mathrm{P}\right) ; 3.37(\mathrm{~m}, 2 \mathrm{H}$, H-2'a,5'b); 3.52 (dd, $\left.1 \mathrm{H}, J_{\text {gem }}=11.9, J_{5^{\prime} \mathrm{a}, 4^{\prime}}=8.4, \mathrm{H}-5^{\prime} \mathrm{a}\right) ; 4.32$ $\left(\mathrm{ddd}, 1 \mathrm{H}, J_{3^{\prime}, 4^{\prime}}=5.0, J_{3^{\prime}, 2^{\prime}}=4.4,3.0, \mathrm{H}-3^{\prime}\right) ; 4.97\left(\mathrm{td}, 1 \mathrm{H}, J_{4^{\prime}, 5^{\prime}}=\right.$ $\left.8.4, J_{4^{\prime}, 3^{\prime}}=5.0, \mathrm{H}-4^{\prime}\right) ; 8.07$ (s, $\left.1 \mathrm{H}, \mathrm{H}-8\right)$.

${ }^{13} \mathrm{C}$ NMR (125.7 MHz, $\left.\mathrm{D}_{2} \mathrm{O}, 25{ }^{\circ} \mathrm{C}\right): 50.47\left(\mathrm{CH}_{2}-5^{\prime}\right) ; 52.25$ $\left(\mathrm{CH}_{2}-2^{\prime}\right) ; 57.95\left(\mathrm{CH}-4^{\prime}\right) ; 70.25\left(\mathrm{~d}, J_{\mathrm{C}, \mathrm{P}}=150.8, \mathrm{CH}_{2} \mathrm{P}\right) ; 82.02(\mathrm{~d}$, $\left.J_{\mathrm{C}, \mathrm{P}}=10.5, \mathrm{CH}-3^{\prime}\right) ; 118.60$ (C-5); 141.99 (CH-8); 154.55 (C-4); 159.62 (C-2); 165.61 (C-6).

${ }^{31} \mathrm{P}\left\{{ }^{1} \mathrm{H}\right\}$ NMR $\left(202.3 \mathrm{MHz}, \mathrm{D}_{2} \mathrm{O}, 25^{\circ} \mathrm{C}\right): 13.85$.

IR $\nu_{\max }(\mathrm{KBr}) 3431$ (vs, br), 1682 (m, br), 1634 (s, br), 1571 (m), 1536 (w), 1480 (w), 1412 (w, br), 1111 (w, br, sh), 1080 (m, br), 973 (w), $802(\mathrm{vw}), 783(\mathrm{w}), 639(\mathrm{w})$.

HRMS (ESI+) for $\mathrm{C}_{10} \mathrm{H}_{15} \mathrm{~N}_{6} \mathrm{O}_{5} \mathrm{PNa}(\mathrm{M}+\mathrm{Na})^{+}$: calcd 353.07338, found 353.07343.

$$
[\alpha]^{20}=+51.5\left(c 0.307, \mathrm{H}_{2} \mathrm{O}\right)
$$

\section{[3S,4R]-(4-(Uracil-1-yl)pyrrolidin-3-yl)oxymethanephosphonic} acid 15d

Reagent $28(0.36 \mathrm{~g}, 1.3 \mathrm{mmol})$ was added to a solution of amino derivative $23(0.45 \mathrm{~g}, 1.18 \mathrm{mmol})$ in dioxane $(12 \mathrm{ml})$. The reaction mixture was stirred at $\mathrm{rt}$ overnight. The mixture 
was concentrated in vacuo and a linear intermediate was obtained by column chromatography on silica gel using a linear gradient of ethanol in chloroform in the form of yellowish foam. Dowex 50 in $\mathrm{H}^{+}$form $(10 \mathrm{~g})$ was added to a solution of the intermediate in dioxane $(15 \mathrm{ml})$. The suspension was stirred at $85{ }^{\circ} \mathrm{C}$ for $5 \mathrm{~h}$. The reaction mixture was filtered; the resin was washed with ethanol $(50 \mathrm{ml})$ and eluted with $3 \%$ aq. ammonia $(100 \mathrm{ml})$. The filtrate was concentrated and the desired product was obtained by preparative reverse phase HPLC with $54 \%$ overall yield $(0.2 \mathrm{~g}, 0.64 \mathrm{mmol})$ after conversion to sodium salt by passing through a column of Dowex 50 in $\mathrm{Na}^{+}$form and lyophilisation from water in the form of a white amorphous solid.

${ }^{1} \mathrm{H}$ NMR (500.0 MHz, $\left.\mathrm{D}_{2} \mathrm{O}, 25^{\circ} \mathrm{C}\right): 3.45\left(\mathrm{dd}, 1 \mathrm{H}, J_{\text {gem }}=12.8\right.$, $\left.J_{2^{\prime} \mathrm{b}, 3^{\prime}}=2.8, \mathrm{H}-2^{\prime} \mathrm{b}\right) ; 3.46\left(\mathrm{dd}, 1 \mathrm{H}, J_{\text {gem }}=12.1, J_{\mathrm{H}, \mathrm{P}}=8.4\right.$, $\left.\mathrm{CH}_{\mathrm{a}} \mathbf{H}_{\mathrm{b}} \mathrm{P}\right) ; 3.50\left(\mathrm{dd}, 1 \mathrm{H}, J_{\text {gem }}=12.1, J_{\mathrm{H}, \mathrm{P}}=10.3, \mathrm{CH}_{\mathrm{a}} \mathrm{H}_{\mathrm{b}} \mathrm{P}\right) ; 3.59$ $\left(\mathrm{dd}, 1 \mathrm{H}, J_{\text {gem }}=12.2, J_{5^{\prime} \mathrm{b}, 4^{\prime}}=9.9, \mathrm{H}-5^{\prime} \mathrm{b}\right) ; 3.73\left(\mathrm{dd}, 1 \mathrm{H}, J_{\text {gem }}=\right.$ $\left.12.2, J_{5^{\prime} \mathrm{a}, 4^{\prime}}=9.9, \mathrm{H}-5^{\prime} \mathrm{a}\right) ; 3.79\left(\mathrm{dd}, 1 \mathrm{H}, J_{\text {gem }}=12.8, J_{2^{\prime} \mathrm{a}, 3^{\prime}}=0.7\right.$, $\left.\mathrm{H}-2^{\prime} \mathrm{a}\right) ; 4.33$ (ddd, $\left.1 \mathrm{H}, J_{3^{\prime}, 4^{\prime}}=4.1, J_{3^{\prime}, 2^{\prime}}=2.8,0.7, \mathrm{H}-3^{\prime}\right) ; 5.36(\mathrm{td}$, $\left.1 \mathrm{H}, J_{4^{\prime}, 5^{\prime}}=9.9, J_{4^{\prime}, 3^{\prime}}=4.1, \mathrm{H}-4^{\prime}\right) ; 5.83\left(\mathrm{~d}, 1 \mathrm{H}, J_{5,6}=8.1, \mathrm{H}-5\right) ; 8.05$ $\left(\mathrm{d}, 1 \mathrm{H}, J_{6,5}=8.1, \mathrm{H}-6\right)$.

${ }^{13} \mathrm{C}$ NMR (125.7 MHz, D $\left.2 \mathrm{O}, 25{ }^{\circ} \mathrm{C}\right): 46.54\left(\mathrm{CH}_{2}-5^{\prime}\right) ; 51.46$ $\left(\mathrm{CH}_{2}-2^{\prime}\right) ; 57.26\left(\mathrm{CH}-4^{\prime}\right) ; 69.83\left(\mathrm{~d}, J_{\mathrm{C}, \mathrm{P}}=150.8, \mathrm{CH}_{2} \mathrm{P}\right) ; 80.57$ (d, $\left.J_{\mathrm{C}, \mathrm{P}}=12.5, \mathrm{CH}-3^{\prime}\right) ; 104.30$ (CH-5); 148.21 (CH-6); 155.48 (C-2); $169.22(\mathrm{C}-4)$.

${ }^{31} \mathrm{P}\left\{{ }^{1} \mathrm{H}\right\}$ NMR $\left(202.3 \mathrm{MHz}, \mathrm{D}_{2} \mathrm{O}, 25^{\circ} \mathrm{C}\right): 12.89$.

IR $\nu_{\max }(\mathrm{KBr}) 3189$ (m, br), 2980 (s), 2936 (m), 1696 (vs, br), 1628 (m), 1480 (m, sh), 1457 (s), 1408 (s), 1387 (s), 1377 (s, sh), 1365 (s, sh), 1279 (s), 1244 (s, br), 1225 (s, sh), 1175 (s), 1142 (s), 1104 (s), 1011 (s, sh), 991 (vs), 888 (m), 768 (m).

HRMS (ESI+) for $\mathrm{C}_{9} \mathrm{H}_{14} \mathrm{O}_{6} \mathrm{~N}_{3} \mathrm{PNa}(\mathrm{M}+\mathrm{Na})^{+}$calcd 314.05124, found 314.05123 .

$[\alpha]^{20}=+88.9\left(c 0.189, \mathrm{H}_{2} \mathrm{O}\right)$.

[3S,4R]-(4-(Thymin-1-yl)pyrrolidin-3-yl)oxymethanephosphonic acid $15 \mathrm{e}$

Reagent $29(0.75 \mathrm{~g}, 2.56 \mathrm{mmol})$ was added to a solution of amino derivative 23 (0.65 g, $1.7 \mathrm{mmol})$ in dioxane $(15 \mathrm{ml})$. The reaction mixture was stirred at rt overnight. The mixture was concentrated in vacuo and a linear intermediate was obtained by column chromatography on silica gel using a linear gradient of ethanol in chloroform in the form of yellowish foam. Dowex 50 in $\mathrm{H}^{+}$form (15 g) was added to a solution of the intermediate in dioxane $(25 \mathrm{ml})$. The suspension was stirred at $85^{\circ} \mathrm{C}$ for $5 \mathrm{~h}$. The reaction mixture was filtered; the resin was washed with ethanol $(50 \mathrm{ml})$ and eluted with $3 \%$ aq. ammonia $(100 \mathrm{ml})$. The filtrate was concentrated and the desired product was obtained by preparative reverse phase HPLC in $32 \%$ overall yield $(175.6 \mathrm{mg}, 0.54 \mathrm{mmol})$ after conversion to sodium salt by passing through a column of Dowex 50 in $\mathrm{Na}^{+}$ form and lyophilisation from water in the form of a white amorphous solid.

${ }^{1} \mathrm{H}$ NMR (500.0 MHz, $\left.\mathrm{D}_{2} \mathrm{O}, 25{ }^{\circ} \mathrm{C}\right): 1.90\left(\mathrm{~d}, 1 \mathrm{H},{ }^{4} J=1.1\right.$, $\left.\mathrm{CH}_{3}\right) ; 3.45\left(\mathrm{dd}, 1 \mathrm{H}, J_{\text {gem }}=12.9, J_{2^{\prime} \mathrm{b}, 3^{\prime}}=3.1, \mathrm{H}-2^{\prime} \mathrm{b}\right) ; 3.52(\mathrm{dd}, 1 \mathrm{H}$, $\left.J_{\text {gem }}=12.4, J_{\mathrm{H}, \mathrm{P}}=8.6, \mathrm{CH}_{\mathrm{a}} \mathbf{H}_{\mathbf{b}} \mathrm{P}\right) ; 3.55\left(\mathrm{dd}, 1 \mathrm{H}, J_{\text {gem }}=12.4, J_{\mathrm{H}, \mathrm{P}}=\right.$ 9.7, $\left.\mathrm{CH}_{\mathrm{a}} \mathrm{H}_{\mathrm{b}} \mathrm{P}\right) ; 3.68\left(\mathrm{dd}, 1 \mathrm{H}, J_{\text {gem }}=12.5, J_{5^{\prime} \mathrm{b}, 4^{\prime}}=10.2, \mathrm{H}-5^{\prime} \mathrm{b}\right)$; $3.74\left(\mathrm{dd}, 1 \mathrm{H}, J_{\text {gem }}=12.5, J_{5^{\prime} \mathrm{a}, 4^{\prime}}=9.6, \mathrm{H}^{-} 5^{\prime} \mathrm{a}\right) ; 3.81\left(\mathrm{~d}, 1 \mathrm{H}, J_{\text {gem }}=\right.$ 12.9, H-2'a); 4.38 (bdd, $\left.1 \mathrm{H}, J_{3^{\prime}, 4^{\prime}}=4.1, J_{3^{\prime}, 2^{\prime}}=3.1, \mathrm{H}-3^{\prime}\right) ; 5.31$ $\left(\mathrm{ddd}, 1 \mathrm{H}, J_{4^{\prime}, 5^{\prime}}=10.2,9.6, J_{4^{\prime}, 3^{\prime}}=4.1, \mathrm{H}-4^{\prime}\right) ; 7.83\left(\mathrm{q}, 1 \mathrm{H},{ }^{4} J=1.1\right.$, H-6).

${ }^{13} \mathrm{C}$ NMR (125.7 MHz, D $\left.2 \mathrm{O}, 25{ }^{\circ} \mathrm{C}\right): 14.23\left(\mathrm{CH}_{3}\right) ; 46.50$ $\left(\mathrm{CH}_{2}-5^{\prime}\right) ; 51.72\left(\mathrm{CH}_{2}-2^{\prime}\right) ; 57.70\left(\mathrm{CH}-4^{\prime}\right) ; 69.67$ (d, $J_{\mathrm{C}, \mathrm{P}}=152.7$, $\mathrm{CH}_{2} \mathrm{P}$ ); 80.67 (d, $\left.J_{\mathrm{C}, \mathrm{P}}=11.9, \mathrm{CH}-3^{\prime}\right) ; 113.32$ (C-5); 143.71 (CH-6); 155.31 (C-2); 169.14 (C-4).

${ }^{31} \mathrm{P}\left\{{ }^{1} \mathrm{H}\right\}$ NMR $\left(202.3 \mathrm{MHz}, \mathrm{D}_{2} \mathrm{O}, 25^{\circ} \mathrm{C}\right): 13.78$.

IR $\nu_{\max }(\mathrm{KBr}) 3260$ (w, vbr, sh), 2831 (w, vvbr), 1695 (vs), 1663 (s, sh), 1521 (w, br), 1473 (w), 1442 (w), 1394 (w), 1375 (w, sh), 1283 (m), 1126 (m), 1072 (m, br), 970 (w), 789 (w), 769 (w).

HRMS (ESI+) for $\mathrm{C}_{10} \mathrm{H}_{15} \mathrm{O}_{6} \mathrm{~N}_{3} \mathrm{P}(\mathrm{M}+\mathrm{H})^{+}$: calcd 304.07039, found 304.06983 .

$$
[\alpha]^{20}=+69.5\left(c 0.364, \mathrm{H}_{2} \mathrm{O}\right) .
$$

\section{[3R,4R]-(4-(Uracil-1-yl)pyrrolidin-3-yl)oxymethanephosphonic acid $16 \mathrm{a}$}

The compound was prepared according to the experimental procedure for compound 15d starting from amino derivative 31 (0.37 g, $0.97 \mathrm{mmol})$ in $43 \%$ overall yield $(0.132 \mathrm{~g}$, $0.42 \mathrm{mmol}$ ) in the form of a white amorphous colorless solid.

${ }^{1} \mathrm{H}$ NMR (500.0 MHz, $\left.\mathrm{D}_{2} \mathrm{O}, 25^{\circ} \mathrm{C}\right): 3.47\left(\mathrm{dd}, 1 \mathrm{H}, J_{\text {gem }}=11.8\right.$, $\left.J_{\mathrm{H}, \mathrm{P}}=10.0, \mathrm{CH}_{\mathrm{a}} \mathbf{H}_{\mathbf{b}} \mathrm{P}\right) ; 3.54\left(\mathrm{dd}, 1 \mathrm{H}, J_{\text {gem }}=11.8, J_{\mathrm{H}, \mathrm{P}}=9.7\right.$, $\left.\mathrm{CH}_{\mathrm{a}} \mathrm{H}_{\mathrm{b}} \mathrm{P}\right) ; 3.57\left(\mathrm{dd}, 1 \mathrm{H}, J_{\text {gem }}=12.7, J_{2^{\prime} \mathrm{b}, 3^{\prime}}=2.4, \mathrm{H}-2^{\prime} \mathrm{b}\right) ; 3.71(\mathrm{dd}$, $\left.1 \mathrm{H}, J_{\text {gem }}=13.1, J_{5^{\prime} \mathrm{b}, 4^{\prime}}=5.3, \mathrm{H}-5^{\prime} \mathrm{b}\right) ; 3.80\left(\mathrm{dd}, 1 \mathrm{H}, J_{\text {gem }}=12.7\right.$, $\left.J_{2^{\prime} \mathrm{a}, 3^{\prime}}=5.4, \mathrm{H}-2^{\prime} \mathrm{a}\right) ; 3.91\left(\mathrm{dd}, 1 \mathrm{H}, J_{\text {gem }}=13.1, J_{5^{\prime} \mathrm{a}, 4^{\prime}}=8.9, \mathrm{H}-5^{\prime} \mathrm{a}\right)$; $4.53\left(\mathrm{ddd}, 1 \mathrm{H}, J_{3^{\prime}, 2^{\prime}}=5.4,2.4, J_{3^{\prime}, 4^{\prime}}=2.0, \mathrm{H}-3^{\prime}\right) ; 4.76(\mathrm{dd}, 1 \mathrm{H}$, $\left.J_{4^{\prime}, 5^{\prime}}=8.9,5.3, J_{4^{\prime}, 3^{\prime}}=2.0, \mathrm{H}-4^{\prime}\right) ; 5.85\left(\mathrm{~d}, 1 \mathrm{H}, J_{5,6}=8.0, \mathrm{H}-5\right) ; 7.72$ $\left(\mathrm{d}, 1 \mathrm{H}, J_{6,5}=8.0, \mathrm{H}-6\right)$.

${ }^{13} \mathrm{C}$ NMR (125.7 MHz, $\left.\mathrm{D}_{2} \mathrm{O}, 25{ }^{\circ} \mathrm{C}\right): 49.39\left(\mathrm{CH}_{2}-5^{\prime}\right) ; 53.29$ $\left(\mathrm{CH}_{2}-2^{\prime}\right) ; 68.82\left(\mathrm{CH}-4^{\prime}\right) ; 69.51\left(\mathrm{~d}, J_{\mathrm{C}, \mathrm{P}}=151.4, \mathrm{CH}_{2} \mathrm{P}\right) ; 85.66(\mathrm{~d}$, $\left.J_{\mathrm{C}, \mathrm{P}}=13.6, \mathrm{CH}-3^{\prime}\right) ; 104.78(\mathrm{CH}-5) ; 149.73$ (CH-6); 154.55 (C-2); $169.26(\mathrm{C}-4)$.

${ }^{31} \mathrm{P}\left\{{ }^{1} \mathrm{H}\right\}$ NMR (202.3 MHz, $\left.\mathrm{D}_{2} \mathrm{O}, 25^{\circ} \mathrm{C}\right): 13.25$.

IR $\nu_{\max }(\mathrm{KBr}) 3500-3000(\mathrm{~m}, \mathrm{vbr}), 2792(\mathrm{~m}, \mathrm{vbr}), 2630(\mathrm{~m}$, br, sh), 2630 (m, br, sh), 2454 (m, vbr), 1695 (vs, br), 1628 (m, br, sh), 1461 (m, sh), 1440 (m), 1389 (m), 1277 (m), 1160 (m, br, sh), 1105 (s, br, sh), 1063 (s, br), 971 (m), 914 (m, br), 767 (m).

HRMS (ESI+) for $\mathrm{C}_{9} \mathrm{H}_{14} \mathrm{O}_{6} \mathrm{~N}_{3} \mathrm{PNa}(\mathrm{M}+\mathrm{Na})^{+}$calcd 314.05124, found 314.05124 .

$[\alpha]^{20}=-66.0\left(c 0.053, \mathrm{H}_{2} \mathrm{O}\right)$.

\section{[3R,4R]-(4-(Hypoxanthin-9-yl)pyrrolidin-3-yl)- oxymethanephosphonic acid $16 \mathrm{~b}$}

A mixture of amino derivative 31 (0.23 g, $0.61 \mathrm{mmol}), 4,6$ dichloro-5-formamidopyrimidine (32) $(0.14 \mathrm{~g}, 0.73 \mathrm{mmol})$, and DIPEA $(0.52 \mathrm{ml}, 3.05 \mathrm{mmol})$ in $n \mathrm{BuOH}(10 \mathrm{ml})$ was stirred at $110{ }^{\circ} \mathrm{C}$ overnight. The reaction mixture was concentrated in vacuo, dissolved in DMF $(5 \mathrm{ml})$, diethoxymethyl acetate ( $3 \mathrm{ml}$ ) was added, and the mixture was stirred at $120^{\circ} \mathrm{C}$ overnight. The chloropurine intermediate was obtained by chromatography on silica gel using a linear gradient of ethanol in chloroform and was used in the next step without further characterisation (except for LCMS). The intermediate $(0.31 \mathrm{~g}$, $0.6 \mathrm{mmol}$ ) was stirred in $1.5 \mathrm{M}$ aq. $\mathrm{HCl}(50 \mathrm{ml})$ at $75^{\circ} \mathrm{C}$ over- 
night, applied on a column of Dowex 50 in $\mathrm{H}^{+}$form $(100 \mathrm{ml})$, washed with $50 \%$ aq. ethanol $(150 \mathrm{ml})$ and eluted with $3 \%$ $\mathrm{NH}_{3}$ in $50 \%$ aq. ethanol $(300 \mathrm{ml})$. The obtained yellow solution was evaporated and purified using preparative HPLC on the reversed phase. The obtained hypoxanthine diisopropyl ester ( $80 \mathrm{mg}, 0.2 \mathrm{mmol})$ was co-evaporated with $\mathrm{MeCN}(3 \times 10 \mathrm{ml})$, dissolved in the same solvent, and $\mathrm{Me}_{3} \mathrm{SiBr}(0.13 \mathrm{ml}, 1 \mathrm{mmol})$ was added under an argon atmosphere. The reaction mixture was stirred under an argon atmosphere at rt overnight. The title compound was obtained by preparative reverse phase HPLC in $10 \%$ overall yield $(21.8 \mathrm{mg}, 65 \mu \mathrm{mol})$ - calculated from 31 - after conversion to sodium salt by passing through a column of Dowex 50 in $\mathrm{Na}^{+}$form and lyophilisation from water in the form of a white amorphous solid.

${ }^{1} \mathrm{H}$ NMR (600.1 MHz, $\left.\mathrm{D}_{2} \mathrm{O}, 25^{\circ} \mathrm{C}\right): 3.60\left(\mathrm{dd}, 1 \mathrm{H}, J_{\text {gem }}=12.1\right.$, $\left.J_{\mathrm{H}, \mathrm{P}}=10.0, \mathrm{CH}_{\mathrm{a}} \mathbf{H}_{\mathbf{b}} \mathrm{P}\right) ; 3.69\left(\mathrm{dd}, 1 \mathrm{H}, J_{\text {gem }}=12.1, J_{\mathrm{H}, \mathrm{P}}=9.5\right.$, $\left.\mathrm{CH}_{\mathrm{a}} \mathrm{H}_{\mathrm{b}} \mathrm{P}\right) ; 3.76\left(\mathrm{dt}, 1 \mathrm{H}, J_{\text {gem }}=13.3, J_{2^{\prime} \mathrm{b}, 3^{\prime}}=J_{2^{\prime} \mathrm{b}, 4^{\prime}}=1.2, \mathrm{H}-2^{\prime} \mathrm{b}\right)$; $3.84\left(\mathrm{dd}, 1 \mathrm{H}, J_{\text {gem }}=13.3, J_{2^{\prime} \mathrm{a}, 3^{\prime}}=4.2, \mathrm{H}-2^{\prime} \mathrm{a}\right) ; 4.07\left(\mathrm{dd}, 1 \mathrm{H}, J_{\text {gem }}=\right.$ 13.6, $\left.J_{5^{\prime} \mathrm{b}, 4^{\prime}}=3.2, \mathrm{H}-5^{\prime} \mathrm{b}\right) ; 4.15\left(\mathrm{dd}, 1 \mathrm{H}, J_{\text {gem }}=13.6, J_{5^{\prime} \mathrm{a}, 4^{\prime}}=7.7\right.$, $\mathrm{H}-5$ 'a); 4.51 (dt, $\left.1 \mathrm{H}, J_{3^{\prime}, 2^{\prime}}=4.2,1.2, J_{3^{\prime}, 4^{\prime}}=1.2, \mathrm{H}-3^{\prime}\right) ; 5.47$ (ddt, $\left.1 \mathrm{H}, J_{4^{\prime}, 5^{\prime}}=7.7,3.2, J_{4^{\prime}, 3^{\prime}}=J_{4^{\prime}, 2^{\prime} \mathrm{b}}=1.2, \mathrm{H}-4^{\prime}\right) ; 8.18(\mathrm{~s}, 1 \mathrm{H}, \mathrm{H}-2)$; 8.25 (s, 1H, H-8).

${ }^{13} \mathrm{C}$ NMR (150.9 MHz, D $\left.2 \mathrm{O}, 25{ }^{\circ} \mathrm{C}\right): 50.33\left(\mathrm{CH}_{2}-5^{\prime}\right) ; 52.42$ $\left(\mathrm{CH}_{2}-2^{\prime}\right) ; 62.19\left(\mathrm{CH}-4^{\prime}\right) ; 69.49\left(\mathrm{~d}, J_{\mathrm{C}, \mathrm{P}}=152.9, \mathrm{CH}_{2} \mathrm{P}\right) ; 86.50(\mathrm{~d}$, $\left.J_{\mathrm{C}, \mathrm{P}}=13.3, \mathrm{CH}-3^{\prime}\right) ; 126.74(\mathrm{C}-5) ; 144.33(\mathrm{CH}-8) ; 148.42(\mathrm{CH}-2)$; 151.25 (C-4); 161.39 (C-6).

${ }^{31} \mathrm{P}\left\{{ }^{1} \mathrm{H}\right\}$ NMR (202.3 MHz, $\left.\mathrm{D}_{2} \mathrm{O}, 25^{\circ} \mathrm{C}\right): 13.57$.

IR $\nu_{\max }(\mathrm{KBr}) 3434$ (vs, br), 3264 (m, br, sh), 2923 (m), 2853 (m), 2790 (m, vbr, sh), 1695 (s), 1588 (m), 1550 (w), 1515 (w), 1470 (w, sh), 1418 (w), 1382 (vw), 1346 (vw), 1216 (w), 1190 (w, br), 1146 (w, vbr), 1112 (w, sh), 1051 (m, br), 912 (w, br), 896 (w, sh), $790(\mathrm{w}), 646(\mathrm{w})$.

HRMS (ESI-) for $\mathrm{C}_{10} \mathrm{H}_{13} \mathrm{~N}_{5} \mathrm{O}_{5} \mathrm{P}(\mathrm{M}-\mathrm{H})^{-}$: calcd 314.06598, found 314.06585 .

$$
[\alpha]^{20}=-30.4\left(c 0.184, \mathrm{H}_{2} \mathrm{O}\right) .
$$

[3R,4R]-(4-(Guanin-9-yl)pyrrolidin-3-yl)oxymethanephosphonic acid $16 \mathrm{c}$

The title compound was prepared from amino derivative 31 $(0.23 \mathrm{~g}, 0.61 \mathrm{mmol})$ and 2-amino-4,6-dichloro-5-formamidopyrimidine (33) ( $0.15 \mathrm{~g}, 0.73 \mathrm{mmol})$ using the same procedure as for compound $\mathbf{1 6 b}$ in $8 \%$ overall yield $(17.3 \mathrm{mg}, 49 \mu \mathrm{mol})$ in the form of a white amorphous solid.

${ }^{1} \mathrm{H}$ NMR (500.0 MHz, $\left.\mathrm{D}_{2} \mathrm{O}, 25{ }^{\circ} \mathrm{C}\right): 3.71\left(\mathrm{dt}, 1 \mathrm{H}, J_{\text {gem }}=13.3\right.$, $\left.J_{2^{\prime} \mathrm{b}, 3^{\prime}}=J_{2^{\prime} \mathrm{b}, 4^{\prime}}=1.4, \mathrm{H}-2^{\prime} \mathrm{b}\right) ; 3.71\left(\mathrm{dd}, 1 \mathrm{H}, J_{\text {gem }}=12.5, J_{\mathrm{H}, \mathrm{P}}=9.9\right.$, $\left.\mathrm{CH}_{\mathrm{a}} \mathbf{H}_{\mathrm{b}} \mathrm{P}\right) ; 3.79\left(\mathrm{dd}, 1 \mathrm{H}, J_{\text {gem }}=12.5, J_{\mathrm{H}, \mathrm{P}}=9.6, \mathrm{CH}_{\mathrm{a}} \mathrm{H}_{\mathrm{b}} \mathrm{P}\right) ; 3.90$ $\left(\mathrm{dd}, 1 \mathrm{H}, J_{\text {gem }}=13.3, J_{2^{\prime} \mathrm{a}, 3^{\prime}}=4.6, \mathrm{H}-2^{\prime} \mathrm{a}\right) ; 4.04\left(\mathrm{dd}, 1 \mathrm{H}, J_{\text {gem }}=\right.$ $\left.13.5, J_{5^{\prime} \mathrm{b}, 4^{\prime}}=3.4, \mathrm{H}-5^{\prime} \mathrm{b}\right) ; 4.08\left(\mathrm{dd}, 1 \mathrm{H}, J_{\text {gem }}=13.5, J_{5^{\prime} \mathrm{a}, 4^{\prime}}=6.7\right.$, $\left.\mathrm{H}-5^{\prime} \mathrm{a}\right) ; 4.52$ (ddd, $\left.1 \mathrm{H}, J_{3^{\prime}, 2^{\prime}}=4.6,1.4, J_{3^{\prime}, 4^{\prime}}=1.9, \mathrm{H}-3^{\prime}\right) ; 5.29(\mathrm{~m}$, $\left.1 \mathrm{H}, \mathrm{H}-4^{\prime}\right) ; 7.89$ (s, 1H, H-8).

${ }^{13} \mathrm{C}$ NMR (125.7 MHz, $\left.\mathrm{D}_{2} \mathrm{O}, 25{ }^{\circ} \mathrm{C}\right): 50.19\left(\mathrm{CH}_{2}-5^{\prime}\right) ; 52.53$ $\left(\mathrm{CH}_{2}-2^{\prime}\right) ; 61.61\left(\mathrm{CH}-4^{\prime}\right) ; 68.89\left(\mathrm{~d}, J_{\mathrm{C}, \mathrm{P}}=155.7, \mathrm{CH}_{2} \mathrm{P}\right) ; 86.68(\mathrm{~d}$, $\left.J_{\mathrm{C}, \mathrm{P}}=13.1, \mathrm{CH}-3^{\prime}\right) ; 119.04$ (C-5); 141.77 (CH-8); 153.73 (C-4); 156.3 (C-2); 161.56 (C-6).

${ }^{31} \mathrm{P}\left\{{ }^{1} \mathrm{H}\right\}$ NMR (202.3 MHz, $\left.\mathrm{D}_{2} \mathrm{O}, 25^{\circ} \mathrm{C}\right): 14.71$.
IR $\nu_{\max }(\mathrm{KBr}) 3311$ (m, vbr), 3117 (m, br), 3022 (m, br, sh), 2749 (m, vbr), 2440 (w, vbr), 1690 (vs), 1658 (s), 1607 (m), 1580 (m, sh), 1536 (w), 1486 (w), 1415 (w), 1374 (w, br), 1117 (m), 1064 (m, br), 970 (w), $779(\mathrm{w}), 691$ (vw), 640 (vw).

HRMS (ESI+) for $\mathrm{C}_{10} \mathrm{H}_{15} \mathrm{~N}_{6} \mathrm{O}_{5} \mathrm{PNa}(\mathrm{M}+\mathrm{Na})^{+}$: calcd 353.07338 , found 353.07346 .

$[\alpha]^{20}=+48.8\left(c 0.172, \mathrm{H}_{2} \mathrm{O}\right)$.

\section{[3S,4S] Diisopropyl 1-N-tert-butyloxycarbonyl-4-} dimethoxytrityloxypyrrolidin-3-yloxymethylphosphonate 18

[3S,4S]-1-N-Boc-3-dimethoxytrityloxy-4-hydroxypyrrolidine (12 g, $34.42 \mathrm{mmol}$ ) diisopropyl tosyloxymethanephosphonate (17.19 g, $49 \mathrm{mmol}$ ) was dissolved in THF (300 ml). The solution was cooled to $0^{\circ} \mathrm{C}$ and sodium hydride $(2.8 \mathrm{~g}, 70 \mathrm{mmol})$ was added. The reaction mixture was stirred at $\mathrm{rt}$ for 3 days and then cooled to $0{ }^{\circ} \mathrm{C}$ and acetic acid $(1.8 \mathrm{ml}, 29 \mathrm{mmol})$ was added slowly. The temperature was allowed to rise to $\mathrm{rt}$ and the solvent was evaporated in vacuo. The title compound was obtained by chromatography on silica gel using a linear gradient of ethyl acetate in toluene as a viscous colorless oil in $77 \%$ yield (14.5 g, $22.11 \mathrm{mmol}$ ).

\section{NMR - (1: 1 mixture of amide rotamers)}

${ }^{1} \mathrm{H}$ NMR (500.0 MHz, $\left.\mathrm{CDCl}_{3}, 25^{\circ} \mathrm{C}\right): 1.24,1.27,1.28,1.29(4 \times$ $\left.\mathrm{d}, 4 \times 6 \mathrm{H}, J_{\text {vic }}=6.2,\left(\mathrm{CH}_{3}\right)_{2} \mathrm{CH}\right) ; 1.41,1.46(2 \times \mathrm{s}, 2 \times 9 \mathrm{H}$, $\left.\left(\mathrm{CH}_{3}\right)_{3} \mathrm{C}\right) ; 2.92\left(\mathrm{~d}, 1 \mathrm{H}, J_{\text {gem }}=12.0, \mathrm{H}-5 \mathrm{~b}\right) ; 3.07\left(\mathrm{dd}, 1 \mathrm{H}, J_{3,4}=\right.$ $\left.4.7, J_{3,2 \mathrm{a}}=4.1, \mathrm{H}-3\right) ; 3.08\left(\mathrm{dd}, 1 \mathrm{H}, J_{\text {gem }}=12.0, J_{5 \mathrm{a}, 4}=4.7, \mathrm{H}-5 \mathrm{a}\right)$; $3.25,3.29\left(2 \times \mathrm{dd}, 2 \times 1 \mathrm{H}, J_{\text {gem }}=13.4, J_{\mathrm{H}, \mathrm{P}}=9.7, \mathrm{CH}_{2} \mathrm{P}\right)$; $3.30-3.33(\mathrm{~m}, 3 \mathrm{H}, \mathrm{H}-3,5) ; 3.34\left(\mathrm{dd}, 1 \mathrm{H}, J_{\text {gem }}=13.2, J_{\mathrm{H}, \mathrm{P}}=9.7\right.$, $\left.\mathrm{CH}_{\mathrm{a}} \mathrm{H}_{\mathrm{b}} \mathrm{P}\right) ; 3.37,3.41\left(2 \times \mathrm{d}, 2 \times 1 \mathrm{H}, J_{\text {gem }}=12.1, \mathrm{H}-2 \mathrm{~b}\right) ; 3.42(\mathrm{dd}$, $\left.1 \mathrm{H}, J_{\text {gem }}=13.2, J_{\mathrm{H}, \mathrm{P}}=9.7, \mathrm{CH}_{\mathrm{a}} \mathrm{H}_{\mathrm{b}} \mathrm{P}\right) ; 3.49,3.56(2 \times \mathrm{dd}, 2 \times 1 \mathrm{H}$, $\left.J_{\text {gem }}=12.1, J_{2 \mathrm{a}, 3}=4.1, \mathrm{H}-2 \mathrm{a}\right) ; 3.786,3.789(2 \times \mathrm{s}, 2 \times 6 \mathrm{H}$, $\mathrm{CH}_{3} \mathrm{O}-\mathrm{DMTr}$ ); 4.10 (bt, $\left.2 \mathrm{H}, J_{4,3}=J_{4,5 \mathrm{a}}=4.7, \mathrm{H}-4\right) ; 4.60-4.70(\mathrm{~m}$, $\left.4 \mathrm{H}, \mathrm{CH}\left(\mathrm{CH}_{3}\right)_{2}\right) ; 6.83,6.84\left(2 \times \mathrm{m}, 2 \times 4 \mathrm{H}, \mathrm{H}-m-\mathrm{C}_{6} \mathrm{H}_{4}-\mathrm{DMTr}\right)$; 7.13-7.36 (m, 14H, H-o- $\left.\mathrm{C}_{6} \mathrm{H}_{4}-\mathrm{DMTr}, \mathrm{H}-m, p-\mathrm{C}_{6} \mathrm{H}_{5}-\mathrm{DMTr}\right) ; 7.43$ (m, $\left.4 \mathrm{H}, \mathrm{H}-\mathrm{o}-\mathrm{C}_{6} \mathrm{H}_{5}-\mathrm{DMTr}\right)$.

${ }^{13} \mathrm{C}$ NMR (125.7 MHz, $\left.\mathrm{CDCl}_{3}, 25{ }^{\circ} \mathrm{C}\right): 23.85,23.97,24.01$ (d, $\left.J_{\mathrm{C}, \mathrm{P}}=4.0,\left(\mathrm{CH}_{3}\right)_{2} \mathrm{CH}\right) ; 28.39,28.45\left(\left(\mathrm{CH}_{3}\right)_{3} \mathrm{C}\right) ; 48.68,49.48\left(\mathrm{CH}_{2}-\right.$ 2); 50.72, $50.82\left(\mathrm{CH}_{2}-5\right) ; 55.17\left(\mathrm{CH}_{3} \mathrm{O}-\mathrm{DMTr}\right) ; 63.92,64.03(\mathrm{~d}$, $\left.J_{\mathrm{C}, \mathrm{P}}=170.0, \mathrm{CH}_{2} \mathrm{P}\right)$; 70.95, 71.03, 71.05, $71.13\left(\mathrm{~d}, J_{\mathrm{C}, \mathrm{P}}=7.0, \mathrm{CH}\right.$ $\left.\left(\mathrm{CH}_{3}\right)_{2}\right)$; 74.27, 75.06 (CH-4); 79.14, $79.24\left(\mathrm{C}\left(\mathrm{CH}_{3}\right)_{3}\right)$; 83.65, 84.37 (d, $\left.J_{\mathrm{C}, \mathrm{P}}=13.0, \mathrm{CH}-3\right) ; 87.10,87.25$ (C-DMTr); 113.22, 113.25 (CH- $m-\mathrm{C}_{6} \mathrm{H}_{4}$-DMTr); 126.99 (CH- $p-\mathrm{C}_{6} \mathrm{H}_{5}-\mathrm{DMTr}$ ); 127.91 (CH- $m-\mathrm{C}_{6} \mathrm{H}_{5}$-DMTr); 128.18, 128.21 (CH-o-C ${ }_{6} \mathrm{H}_{5}-\mathrm{DMTr}$ ); 130.10, 130.14 (CH-m- $\left.\mathrm{C}_{6} \mathrm{H}_{4}-\mathrm{DMTr}\right) ; 136.11,136.20,136.30\left(\mathrm{C}-\mathrm{i}-\mathrm{C}_{6} \mathrm{H}_{4}-\right.$ DMTr); 144.97, 145.03 (C-i-C ${ }_{6} \mathrm{H}_{5}-\mathrm{DMTr}$ ); 154.54, 154.66 (CO); 158.67, 158.70 (C-p- $\mathrm{C}_{6} \mathrm{H}_{4}$-DMTr).

${ }^{31} \mathrm{P}\left\{{ }^{1} \mathrm{H}\right\}$ NMR $\left(202.3 \mathrm{MHz}, \mathrm{CDCl}_{3}, 25{ }^{\circ} \mathrm{C}\right): 19.00,19.05$.

HRMS $(\mathrm{FAB}+)$ for $\mathrm{C}_{37} \mathrm{H}_{50} \mathrm{NO}_{9} \mathrm{PNa}(\mathrm{M}+\mathrm{H}+\mathrm{Na})^{+}$: calcd 706.3121, found 706.3146.

[3S,4S] Diisopropyl 1-N-tert-butyloxycarbonyl-4hydroxypyrrolidin-3-yloxymethylphosphonate 19

2\% TFA in DCM (200 ml) was added to compound 18 (14.5 g, $22.11 \mathrm{mmol}$ ) and the reaction mixture was stirred until the DMTr group was cleaved completely (followed by TLC, 
$\sim 20 \mathrm{~min}) . \mathrm{NaHCO}_{3}(20 \mathrm{~g})$ and $\mathrm{MeOH}(50 \mathrm{ml})$ were added and the suspension was vigorously stirred until neutral $\mathrm{pH}$. The suspension was filtered over celite and the filtrate was evaporated. The title compound was obtained by chromatography on silica gel using a linear gradient of ethanol in chloroform in $83 \%$ yield $(6.97 \mathrm{~g}, 18.28 \mathrm{mmol}$ ) in the form of colorless oil that upon keeping in a refrigerator (at $4{ }^{\circ} \mathrm{C}$ ) starts to crystallize after several days.

\section{NMR - (1:1 mixture of amide rotamers)}

${ }^{1} \mathrm{H}$ NMR (499.8 MHz, DMSO- $\left.d_{6}, 25{ }^{\circ} \mathrm{C}\right): 1.22,1.23,1.24(3 \times \mathrm{d}$, $\left.24 \mathrm{H}, J_{\text {vic }}=6.2,\left(\mathrm{CH}_{3}\right)_{2} \mathrm{CH}\right) ; 1.38,1.39\left(2 \times \mathrm{s}, 2 \times 9 \mathrm{H},\left(\mathrm{CH}_{3}\right)_{3} \mathrm{C}\right)$; $3.14,3.15\left(2 \times \mathrm{d}, 2 \times 1 \mathrm{H}, J_{\text {gem }}=11.4, \mathrm{H}-5 \mathrm{~b}\right) ; 3.26,3.29(2 \times \mathrm{dd}$, $\left.2 \times 1 \mathrm{H}, J_{\text {gem }}=11.4, J_{5 \mathrm{a}, 4}=4.4, \mathrm{H}-5 \mathrm{a}\right) ; 3.30-3.34(\mathrm{~m}, 3 \mathrm{H}, 2 \times$ $\mathrm{H}-2 \mathrm{~b}, \mathrm{H}-2 \mathrm{a}$ ); 3.37 (dd, $\left.1 \mathrm{H}, J_{\text {gem }}=12.2, J_{2 \mathrm{a}, 3}=4.1, \mathrm{H}-2 \mathrm{a}\right) ; 3.77$ $\left(\mathrm{dd}, 1 \mathrm{H}, J_{\text {gem }}=13.1, J_{\mathrm{H}, \mathrm{P}}=9.0, \mathrm{CH}_{\mathrm{a}} \mathbf{H}_{\mathbf{b}} \mathrm{P}\right) ; 3.79\left(\mathrm{~d}, 2 \mathrm{H}, J_{\mathrm{H}, \mathrm{P}}=9.0\right.$, $\left.\mathrm{CH}_{2} \mathrm{P}\right) ; 3.81\left(\mathrm{dd}, 1 \mathrm{H}, J_{\text {gem }}=13.1, J_{\mathrm{H}, \mathrm{P}}=9.0, \mathrm{CH}_{\mathrm{a}} \mathrm{H}_{\mathrm{b}} \mathrm{P}\right) ; 3.83(\mathrm{~m}$, $2 \mathrm{H}, \mathrm{H}-3) ; 4.08,4.10(2 \times \mathrm{m}, 2 \times 1 \mathrm{H}, \mathrm{H}-4) ; 4.58(\mathrm{~m}, 4 \mathrm{H}$, $\left.\mathrm{CH}\left(\mathrm{CH}_{3}\right)_{2}\right) ; 5.249,5.253\left(2 \times \mathrm{d}, 2 \times 1 \mathrm{H}, \mathrm{J}_{\mathrm{OH}, 3}=3.6, \mathrm{OH}\right)$.

${ }^{13} \mathrm{C}$ NMR (125.7 MHz, DMSO- $\left.d_{6}, 25{ }^{\circ} \mathrm{C}\right): 23.84,23.86(\mathrm{~d}$, $\left.J_{\mathrm{C}, \mathrm{P}}=4.4,\left(\mathrm{CH}_{3}\right)_{2} \mathrm{CH}\right) ; 24.00,24.01\left(\mathrm{~d}, J_{\mathrm{C}, \mathrm{P}}=3.6,\left(\mathrm{CH}_{3}\right)_{2} \mathrm{CH}\right)$; $28.34\left(\left(\mathrm{CH}_{3}\right)_{3} \mathrm{C}\right) ; 48.85,49.23\left(\mathrm{CH}_{2}-2\right)$; 51.97, $52.26\left(\mathrm{CH}_{2}-5\right)$; 63.05, $63.19\left(\mathrm{~d}, J_{\mathrm{C}, \mathrm{P}}=165.4, \mathrm{CH}_{2} \mathrm{P}\right) ; 70.44,70.46,70.47\left(\mathrm{~d}, J_{\mathrm{C}, \mathrm{P}}=\right.$

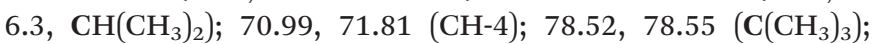
$83.92\left(\mathrm{~d}, J_{\mathrm{C}, \mathrm{P}}=12.3, \mathrm{CH}-3\right) ; 84.83\left(\mathrm{~d}, J_{\mathrm{C}, \mathrm{P}}=12.0, \mathrm{CH}-3\right) ; 153.97$, $153.99(\mathrm{CO})$.

${ }^{31} \mathrm{P}\left\{{ }^{1} \mathrm{H}\right\}$ NMR (202.3 MHz, DMSO- $\left.d_{6}, \mathrm{CDCl}_{3}, 25{ }^{\circ} \mathrm{C}\right): 20.12$, 20.17 .

IR $\nu_{\max }\left(\mathrm{CHCl}_{3}\right) 3610(\mathrm{w}), 3363(\mathrm{~m}, \mathrm{vbr}), 2983(\mathrm{vs}), 2936(\mathrm{~s})$, 1689 (vs), 1679 (vs, sh), 1478 (s), 1467 (m), 1455 (s), 1415 (vs, br), 1389 (s), 1377 (s), 1368 (s), 1245 (s, br), 1170 (vs), 1143 (s), 1105 (vs), 1002 (vs, vbr), 889 (m).

HRMS (ESI + ) for $\mathrm{C}_{16} \mathrm{H}_{32} \mathrm{NO}_{7} \mathrm{PNa}(\mathrm{M}+\mathrm{Na})^{+}$calcd 404.18141, found 404.18153 .

\section{[3S,4S] Diisopropyl 1-N-tert-butyloxycarbonyl-4-} mesyloxypyrrolidin-3-yloxymethylphosphonate 20

Mesyl chloride (4.26 ml, $55 \mathrm{mmol}$ ) was added to a solution of 19 (6.97 g, $18.28 \mathrm{mmol}$ ) and DMAP (6.7 g, $55 \mathrm{mmol}$ ) in DCM $(130 \mathrm{ml})$ at $0{ }^{\circ} \mathrm{C}$. The reaction mixture was stirred at $\mathrm{rt}$ for $2 \mathrm{~h}$. The reaction mixture was washed with a saturated solution of sodium bicarbonate. The organic phase was evaporated and the title compound was obtained by chromatography on silica gel using a linear gradient of ethyl acetate in toluene as a colorless syrup in $92 \%$ yield $(7.71 \mathrm{~g}, 16.78 \mathrm{mmol})$.

\section{NMR - (1: 1 mixture of amide rotamers)}

${ }^{1} \mathrm{H}$ NMR (499.9 MHz, $\left.\mathrm{CDCl}_{3}, 25{ }^{\circ} \mathrm{C}\right): 1.33,1.34,1.35(3 \times \mathrm{d}$, $\left.24 \mathrm{H}, J_{\text {vic }}=6.2,\left(\mathrm{CH}_{3}\right)_{2} \mathrm{CH}\right) ; 1.47\left(\mathrm{~s}, 18 \mathrm{H},\left(\mathrm{CH}_{3}\right)_{3} \mathrm{C}\right) ; 3.09,3.11(2$ $\times$ bs, $\left.2 \times 3 \mathrm{H}, \mathrm{CH}_{3}-\mathrm{Ms}\right) ; 3.48-3.73(\mathrm{~m}, 8 \mathrm{H}, \mathrm{H}-2,5) ; 3.75-3.84(\mathrm{~m}$, $4 \mathrm{H}, \mathrm{CH}_{2} \mathrm{P}$ ); 4.27 (bm, 2H, H-3); 4.68-4.82 (m, $\left.4 \mathrm{H}, \mathrm{CH}\left(\mathrm{CH}_{3}\right)_{2}\right)$; $5.13(\mathrm{~m}, 2 \mathrm{H}, \mathrm{H}-4)$.

${ }^{13} \mathrm{C}$ NMR $\left(125.7 \mathrm{MHz}, \mathrm{CDCl}_{3}, 25{ }^{\circ} \mathrm{C}\right): 23.91,23.94\left(\mathrm{~d}, J_{\mathrm{C}, \mathrm{P}}=\right.$ 4.2, $\left.\left(\mathrm{CH}_{3}\right)_{2} \mathrm{CH}\right) ; 23.99,24.01\left(\mathrm{~d}, J_{\mathrm{C}, \mathrm{P}}=3.5,\left(\mathrm{CH}_{3}\right)_{2} \mathrm{CH}\right) ; 28.35$ $\left(\left(\mathrm{CH}_{3}\right)_{3} \mathrm{C}\right) ; 38.63\left(\mathrm{CH}_{3}-\mathrm{Ms}\right) ; 48.61\left(\mathrm{CH}_{2}-2\right) ; 49.31\left(\mathrm{CH}_{2}-2,5\right)$; $49.83\left(\mathrm{CH}_{2}-5\right) ; 64.57,64.63\left(\mathrm{~d}, J_{\mathrm{C}, \mathrm{P}}=169.3, \mathrm{CH}_{2} \mathrm{P}\right) ; 71.26-71.51$
$\left(\mathrm{CH}\left(\mathrm{CH}_{3}\right)_{2}\right) ; 79.45(\mathrm{CH}-4) ; 80.08\left(\mathrm{C}\left(\mathrm{CH}_{3}\right)_{3}\right) ; 80.13$ (CH-4); 82.10, $83.29\left(\mathrm{~d}, J_{\mathrm{C}, \mathrm{P}}=10.4, \mathrm{CH}-3\right) ; 154.02,154.08(\mathrm{CO})$.

${ }^{31} \mathrm{P}\left\{{ }^{1} \mathrm{H}\right\}$ NMR $\left(202.3 \mathrm{MHz}, \mathrm{CDCl}_{3}, 25{ }^{\circ} \mathrm{C}\right): 18.28,18.30$.

HRMS (ESI + ) for $\mathrm{C}_{17} \mathrm{H}_{34} \mathrm{NO}_{9} \mathrm{PSNa}(\mathrm{M}+\mathrm{Na})^{+}$calcd 482.15896, found 482.15880.

\section{[3S,4R] Diisopropyl 4-azido1-1-N-tert-} butyloxycarbonylpyrrolidin-3-yloxymethylphosphonate 21

Method A. Sodium azide $(1.3 \mathrm{~g}, 20 \mathrm{mmol})$ was added to a solution of 20 (4.63 g, $10.08 \mathrm{mmol})$ in DMF $(50 \mathrm{ml})$. The reaction mixture was stirred at $95{ }^{\circ} \mathrm{C}$ overnight. Sodium azide (1.3 $\mathrm{g}, 20 \mathrm{mmol})$ was added and the reaction mixture was stirred at $120{ }^{\circ} \mathrm{C}$ for an additional $12 \mathrm{~h}$. The reaction mixture was filtered, and the filtrate was evaporated. The title compound was obtained by chromatography on silica gel using a linear gradient of ethanol in chloroform in 53\% yield $(2.17 \mathrm{~g}$, $5.34 \mathrm{mmol}$ ) in the form of colorless oil.

Method B. Sodium hydride $(1.16 \mathrm{~g}, 29 \mathrm{mmol})$ was added to a solution of compound 22 (3.31 g, $14.5 \mathrm{mmol})$ and diisopropyl tosyloxymethanephosphonate $(7.62 \mathrm{~g}, 21.75 \mathrm{mmol})$ in THF $(150 \mathrm{ml})$. The reaction mixture was stirred at $\mathrm{rt}$ overnight. The reaction mixture was cooled to $-5{ }^{\circ} \mathrm{C}$ and acetic acid (1.66 $\mathrm{ml}, 29 \mathrm{mmol}$ ) was added (hydrogen is formed!). The reaction mixture was stirred at rt for $10 \mathrm{~min}$, concentrated in vacuo and the title compound was obtained by chromatography on silica gel using a linear gradient of ethanol in chloroform in $75 \%$ yield $(4.4 \mathrm{~g}, 10.83 \mathrm{mmol})$ in the form of colorless oil.

\section{NMR - (1: 1 mixture of amide rotamers)}

${ }^{1} \mathrm{H}$ NMR $\left(500.0 \mathrm{MHz}, \mathrm{CDCl}_{3}, 25{ }^{\circ} \mathrm{C}\right): 1.35,1.35(2 \times \mathrm{d}, 2 \times 12 \mathrm{H}$, $\left.J_{\text {vic }}=6.1,\left(\mathrm{CH}_{3}\right)_{2} \mathrm{CH}\right) ; 1.45\left(\mathrm{~s}, 18 \mathrm{H},\left(\mathrm{CH}_{3}\right)_{3} \mathrm{C}\right) ; 3.40(\mathrm{dd}, 1 \mathrm{H}$, $\left.J_{\text {gem }}=11.0, J_{2 \mathrm{~b}, 3}=4.6, \mathrm{H}-2 \mathrm{~b}\right) ; 3.41\left(\mathrm{dd}, 1 \mathrm{H}, J_{\text {gem }}=10.6, J_{5 \mathrm{~b}, 4}=\right.$ 4.6, H-5b); 3.48 (m, 2H, H-2b,5b); 3.54-3.60 (m, 4H, H-2a,5a); 3.79-3.89 (m, 4H, $\left.\mathrm{CH}_{2} \mathrm{P}\right)$; 3.91, $3.95(2 \times \mathrm{m}, 2 \times 1 \mathrm{H}, \mathrm{H}-4) ; 4.28$, $4.29(2 \times \mathrm{m}, 2 \times 1 \mathrm{H}, \mathrm{H}-3)$; 4.71-4.83 (m, 4H, CH$\left.\left(\mathrm{CH}_{3}\right)_{2}\right)$.

${ }^{13} \mathrm{C}$ NMR (125.7 MHz, $\left.\mathrm{CDCl}_{3}, 25{ }^{\circ} \mathrm{C}\right): 23.94\left(\mathrm{~d}, J_{\mathrm{C}, \mathrm{P}}=4.5\right.$, $\left.\left(\mathrm{CH}_{3}\right)_{2} \mathrm{CH}\right) ; 24.03,24.04\left(\mathrm{~d}, J_{\mathrm{C}, \mathrm{P}}=3.9,\left(\mathrm{CH}_{3}\right)_{2} \mathrm{CH}\right) ; 28.37$ $\left(\left(\mathrm{CH}_{3}\right)_{3} \mathrm{C}\right)$; 47.59, 47.75, $48.16\left(\mathrm{CH}_{2}-2,5\right) ; 59.73,60.30$ (CH-4); $64.64,64.92\left(\mathrm{~d}, J_{\mathrm{C}, \mathrm{P}}=167.9, \mathrm{CH}_{2} \mathrm{P}\right) ; 71.36\left(\mathrm{~d}, J_{\mathrm{C}, \mathrm{P}}=6.7\right.$,

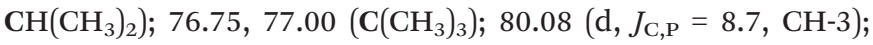
$80.86\left(\mathrm{~d}, J_{\mathrm{C}, \mathrm{P}}=9.2, \mathrm{CH}-3\right) ; 154.10(\mathrm{CO})$.

${ }^{31} \mathrm{P}\left\{{ }^{1} \mathrm{H}\right\}$ NMR $\left(202.3 \mathrm{MHz}, \mathrm{CDCl}_{3}, 25{ }^{\circ} \mathrm{C}\right): 18.41,18.44$.

HRMS (ESI+) for $\mathrm{C}_{16} \mathrm{H}_{31} \mathrm{~N}_{4} \mathrm{O}_{6} \mathrm{PNa}(\mathrm{M}+\mathrm{H}+\mathrm{Na})^{+}$: calcd 429.1879, found 429.1876 .

[3S,4R] 4-Azido-1- $N$-tert-butyloxycarbonyl-3-hydroxypyrrolidine 22

$\mathrm{MsCl}(20 \mathrm{ml}, 260 \mathrm{mmol})$ was added dropwise to a solution of dimethoxytrityl derivative 17 (64.6 g, $127.77 \mathrm{mmol}$ ) and DMAP $(32 \mathrm{~g}, 260 \mathrm{mmol})$ in DCM $(1 \mathrm{~L})$ at $0{ }^{\circ} \mathrm{C}$. The reaction mixture was stirred at $\mathrm{rt}$ overnight. The mixture was washed with sat. aq. $\mathrm{NaHCO}_{3}(2 \times 400 \mathrm{ml}), 10 \%$ aq. citric acid $(2 \times 400 \mathrm{ml})$ and water $(2 \times 400 \mathrm{ml})$. The organic phase was dried over sodium sulfate, filtered and concentrated in vacuo. The residue was dissolved in DMF (1 L). Sodium azide (26 g, $400 \mathrm{mmol}$ ) was added and the reaction mixture was stirred at $110^{\circ} \mathrm{C}$ overnight. The reaction mixture was concentrated in vacuo. Ethyl acetate 
(500 $\mathrm{ml}$ ) was added to the residue. The slurry was filtered and concentrated in vacuo. $1.5 \%$ TFA in DCM $(600 \mathrm{ml})$ was added and the mixture was stirred until complete removal of the DMTr group (followed by TLC in 50\% EtOAc/toluene and 10\% EtOH in chloroform) for ca. 2 h. Solid $\mathrm{NaHCO}_{3}(40 \mathrm{~g})$ and $\mathrm{MeOH}(100 \mathrm{ml})$ were added in portions. The mixture was vigorously stirred until the $\mathrm{pH}$ was neutral ( $\sim 30 \mathrm{~min})$. The suspension was filtered and the filtrate was concentrated in vacuo. The title compound was obtained by chromatography on silica gel using a linear gradient of ethyl acetate in toluene with $77 \%$ yield (over three steps) (22.6 g, $99 \mathrm{mmol}$ ) in the form of colorless oil that solidified on keeping in the refrigerator.

${ }^{1} \mathrm{H}$ NMR (499.8 MHz, DMSO- $\left.d_{6}, 80{ }^{\circ} \mathrm{C}\right): 1.41(\mathrm{~s}, 9 \mathrm{H}$, $\left.\left(\mathrm{CH}_{3}\right)_{3} \mathrm{C}\right) ; 3.13\left(\mathrm{dd}, 1 \mathrm{H}, J_{\text {gem }}=10.9, J_{2 \mathrm{~b}, 3}=5.5, \mathrm{H}-2 \mathrm{~b}\right) ; 3.23(\mathrm{dd}$, $\left.1 \mathrm{H}, J_{\text {gem }}=11.3, J_{5 \mathrm{~b}, 4}=5.0, \mathrm{H}-5 \mathrm{~b}\right) ; 3.42\left(\mathrm{dd}, 1 \mathrm{H}, J_{\text {gem }}=10.9\right.$, $\left.J_{2 \mathrm{a}, 3}=6.0, \mathrm{H}-2 \mathrm{a}\right) ; 3.46\left(\mathrm{dd}, 1 \mathrm{H}, J_{\text {gem }}=11.3, J_{5 \mathrm{a}, 4}=6.0, \mathrm{H}-5 \mathrm{a}\right)$; $3.92\left(\mathrm{ddd}, 1 \mathrm{H}, J_{4,5}=6.0,5.0, J_{4,3}=4.4, \mathrm{H}-4\right) ; 4.33(\mathrm{~m}, 1 \mathrm{H}, \mathrm{H}-3)$; 5.36 (bs, $1 \mathrm{H}, \mathrm{OH})$.

${ }^{13} \mathrm{C}$ NMR (125.7 MHz, DMSO- $\left.d_{6}, 80{ }^{\circ} \mathrm{C}\right): 28.00\left(\left(\mathrm{CH}_{3}\right)_{3} \mathrm{C}\right)$; $47.45\left(\mathrm{CH}_{2}-5\right) ; 50.44\left(\mathrm{CH}_{2}-2\right) ; 61.24(\mathrm{CH}-4) ; 70.52$ (CH-3); 78.50 $\left(\left(\mathrm{CH}_{3}\right)_{3} \mathrm{C}\right) ; 153.40(\mathrm{CO})$.

IR $\nu_{\max }(\mathrm{KBr}) 3340(\mathrm{~m}), 2980(\mathrm{~m}), 2942(\mathrm{w}), 2138(\mathrm{~m}), 2124$ (s, sh), 2095 (s), 1682 (s), 1479 (m), 1470 (m), 1455 (m, sh), 1420 (vs), 1391 (m, sh), 1369 (m), 1217 (w), 1257 (m), 1163 (s), 1093 (m, sh), $552(\mathrm{w})$.

HRMS (ESI+) for $\mathrm{C}_{9} \mathrm{H}_{16} \mathrm{~N}_{4} \mathrm{O}_{3} \mathrm{Na}(\mathrm{M}+\mathrm{Na})^{+}$calcd 251.1115, found 251.1114.

$[3 S, 4 R]$ Diisopropyl 4-amino-1-N-tert-butyloxycarbonylpyrrolidin3-yloxymethylphosphonate 23

A solution of $21(2.17 \mathrm{~g}, 5.34 \mathrm{mmol})$ in ethanol $(50 \mathrm{ml})$ was hydrogenated in the presence of $\mathrm{Pd} / \mathrm{C}(0.2 \mathrm{~g})$ overnight. The suspension was filtered over celite and this was evaporated. The title compound was obtained without further purification in $79 \%$ yield $(1.61 \mathrm{~g}, 4.232 \mathrm{mmol})$ in the form of colorless oil.

\section{NMR - (1:1 mixture of amide rotamers)}

${ }^{1} \mathrm{H}$ NMR (500.0 MHz, DMSO- $\left.d_{6}, 25{ }^{\circ} \mathrm{C}\right): 1.21-1.26(\mathrm{~m}, 24 \mathrm{H}$, $\left.\left(\mathrm{CH}_{3}\right)_{2} \mathrm{CH}\right) ; 1.375,1.378\left(2 \times \mathrm{s}, 2 \times 9 \mathrm{H},\left(\mathrm{CH}_{3}\right)_{3} \mathrm{C}\right) ; 2.82,2.84(2 \times$ $\left.\mathrm{dd}, 2 \times 1 \mathrm{H}, J_{\text {gem }}=9.9, J_{5 \mathrm{~b}, 4}=7.5, \mathrm{H}-5 \mathrm{~b}\right) ; 3.25\left(\mathrm{dd}, 2 \mathrm{H}, J_{\text {gem }}=\right.$ $\left.12.1, J_{2 \mathrm{~b}, 3}=4.3, \mathrm{H}-2 \mathrm{~b}\right) ; 3.29-3.43$ (m, 6H, H-2a,4,5a); 3.77-3.85 $\left(\mathrm{m}, 4 \mathrm{H}, \mathrm{H}-3, \mathrm{CH}_{\mathrm{a}} \mathbf{H}_{\mathbf{b}} \mathrm{P}\right) ; 3.88\left(\mathrm{dd}, 2 \mathrm{H}, J_{\text {gem }}=13.9, J_{\mathrm{H}, \mathrm{P}}=8.9\right.$, $\left.\mathrm{CH}_{\mathrm{a}} \mathrm{H}_{\mathrm{b}} \mathrm{P}\right) ; 4.54-4.66\left(\mathrm{~m}, 4 \mathrm{H}, \mathrm{CH}\left(\mathrm{CH}_{3}\right)_{2}\right)$.

${ }^{13} \mathrm{C}$ NMR $\left(125.7 \mathrm{MHz}\right.$, DMSO- $\left.d_{6}, 25^{\circ} \mathrm{C}\right): 23.87\left(\mathrm{~d}, J_{\mathrm{C}, \mathrm{P}}=4.0\right.$, $\left.\left(\mathrm{CH}_{3}\right)_{2} \mathrm{CH}\right)$; 24.00, $24.05\left(\mathrm{~d}, J_{\mathrm{C}, \mathrm{P}}=3.6,\left(\mathrm{CH}_{3}\right)_{2} \mathrm{CH}\right) ; 28.32$ $\left(\left(\mathrm{CH}_{3}\right)_{3} \mathrm{C}\right)$; 48.99, $49.40\left(\mathrm{CH}_{2}-2\right)$; 50.47, $50.87\left(\mathrm{CH}_{2}-5\right) ; 52.34$, $53.18(\mathrm{CH}-4) ; 63.78,64.01\left(\mathrm{~d}, J_{\mathrm{C}, \mathrm{P}}=164.5, \mathrm{CH}_{2} \mathrm{P}\right) ; 70.44-71.54$ $\left(\mathrm{CH}\left(\mathrm{CH}_{3}\right)_{2}\right) ; 78.51\left(\mathrm{C}\left(\mathrm{CH}_{3}\right)_{3}\right) ; 80.94\left(\mathrm{~d}, J_{\mathrm{C}, \mathrm{P}}=12.0, \mathrm{CH}-3\right) ; 81.67$ $\left(\mathrm{d}, J_{\mathrm{C}, \mathrm{P}}=11.6, \mathrm{CH}-3\right) ; 153.69,153.79$ (CO).

${ }^{31} \mathrm{P}\left\{{ }^{1} \mathrm{H}\right\}$ NMR (202.3 MHz, DMSO- $\left.d_{6}, 25^{\circ} \mathrm{C}\right): 20.32,20.36$.

HRMS (ESI+) for $\mathrm{C}_{16} \mathrm{H}_{33} \mathrm{~N}_{2} \mathrm{O}_{6} \mathrm{PNa}(\mathrm{M}+\mathrm{H}+\mathrm{Na})^{+}$: calcd 403.1968, found 403.1971.

\section{[3S,4R] Diisopropyl 4-(6-chloropurin-9-yl)-1-N-tert-} butyloxycarbonylpyrrolidin-3-yloxymethylphosphonate 25

DIAD (1.81 ml, $9.36 \mathrm{mmol})$ was added to a solution of triphenylphosphine $(1.52 \mathrm{~g}, 9.36 \mathrm{mmol})$ in THF (30 ml). The mixture was stirred at $\mathrm{rt}$ for $3 \mathrm{~h}$. A mixture of 19 (1.19 g, $3.12 \mathrm{mmol})$ and 6-chloropurine $(0.58 \mathrm{~g}, 3.74 \mathrm{mmol})$ in THF $(30 \mathrm{ml})$ was added. The suspension turned to a clear red-brown solution in $5 \mathrm{~min}$. The reaction mixture was stirred at $\mathrm{rt}$ for an additional $2 \mathrm{~h}$. The solvent was removed in vacuo and the title compound was obtained by column chromatography on silica gel using a linear gradient of ethyl acetate in toluene in $53 \%$ yield $(0.85 \mathrm{~g}$, $1.64 \mathrm{mmol})$.

\section{NMR - (1:1 mixture of amide rotamers)}

${ }^{1} \mathrm{H}$ NMR (600.1 MHz, DMSO- $\left.d_{6}, 25{ }^{\circ} \mathrm{C}\right): 0.98,1.00,1.05,1.07$, $1.13\left(5 \times \mathrm{d}, 24 \mathrm{H}, J_{\text {vic }}=6.1,\left(\mathrm{CH}_{3}\right)_{2} \mathrm{CH}\right) ; 1.42,1.44(2 \times \mathrm{s}, 2 \times 9 \mathrm{H}$, $\left.\left(\mathrm{CH}_{3}\right)_{3} \mathrm{C}\right) ; 3.51-3.71\left(\mathrm{~m}, 6 \mathrm{H}, \mathrm{H}-2^{\prime}, \mathrm{CH}_{\mathrm{a}} \mathrm{H}_{\mathbf{b}} \mathrm{P}\right) ; 3.83-3.90(\mathrm{~m}, 4 \mathrm{H}$, $\left.\mathrm{H}-5^{\prime} \mathrm{b}, \mathrm{CH}_{\mathrm{a}} \mathrm{H}_{\mathrm{b}} \mathrm{P}\right) ; 3.956,3.962\left(2 \times \mathrm{dd}, 2 \times 1 \mathrm{H}, J_{\text {gem }}=9.9, J_{5^{\prime} \mathrm{a}, 4^{\prime}}=\right.$ 8.9, H-5'a); 4.29-4.44 (m, 4H, H-3', $\left.\mathrm{CH}_{\mathrm{a}} \mathbf{H}_{\mathbf{b}} \mathrm{P}\right) ; 5.37,5.38(2 \times \mathrm{td}$, $\left.2 \times 1 \mathrm{H}, J_{3^{\prime}, 4^{\prime}}=8.9, J_{3^{\prime}, 2^{\prime}}=8.9,4.2, \mathrm{H}-3^{\prime}\right) ; 8.71,8.72(2 \times \mathrm{s}, 2 \times 1 \mathrm{H}$, $\mathrm{H}-8) ; 8.80$ (s, 2H, H-2).

${ }^{13} \mathrm{C}$ NMR $\left(150.9 \mathrm{MHz}, \mathrm{DMSO}-d_{6}, 25{ }^{\circ} \mathrm{C}\right): 23.62,23.71,23.73$ $\left(\mathrm{d}, J_{\mathrm{C}, \mathrm{P}}=4.4,\left(\mathrm{CH}_{3}\right)_{2} \mathrm{CH}\right) ; 23.81,23.87\left(\mathrm{~d}, J_{\mathrm{C}, \mathrm{P}}=3.8,\left(\mathrm{CH}_{3}\right)_{2} \mathrm{CH}\right)$; $28.37\left(\left(\mathrm{CH}_{3}\right)_{3} \mathrm{C}\right) ; 4.69,46.90\left(\mathrm{CH}_{2}-5^{\prime}\right) ; 48.87,49.34\left(\mathrm{CH}_{2}-2^{\prime}\right)$; 54.54, 55.02 (CH-3'); 63.08, 63.30 (d, $\left.J_{\mathrm{C}, \mathrm{P}}=164.0, \mathrm{CH}_{2} \mathrm{P}\right) ; 70.36$, $70.38\left(\mathrm{~d}, J_{\mathrm{C}, \mathrm{P}}=6.0, \mathrm{CH}\left(\mathrm{CH}_{3}\right)_{2}\right) ; 70.49\left(\mathrm{~d}, J_{\mathrm{C}, \mathrm{P}}=6.3, \mathrm{CH}\left(\mathrm{CH}_{3}\right)_{2}\right)$;

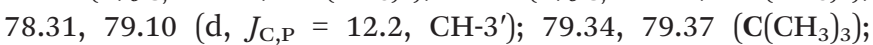
130.85, 130.90 (C-5); 147.06 (CH-8); 149.27 (C-6); 151.77 (CH-2); 152.52 (C-4); 153.76, 153.79 (CO).

${ }^{31} \mathrm{P}\left\{{ }^{1} \mathrm{H}\right\}$ NMR (202.3 MHz, DMSO- $\left.d_{6}, 25^{\circ} \mathrm{C}\right): 19.45,19.54$.

IR $\nu_{\text {max }}(\mathrm{KBr}) 2976$ (s), 1705 (s, sh), 1679 (vs), 1596 (s), 1558 (m), 1492 (m), 1479 (m), 1465 (m), 1435 (s), 1415 (vs), 1399 (vs), 1388 (s, sh), 1372 (s), 1365 (s, sh), 1340 (s), 1259 (s), 1232 (s), 1228 (s), 1212 (m, sh), 1175 (s, sh), 1167 (s), 1140 (s), 1105 (s), 1008 (vs), 987 (vs), 933 (m), 884 (m), 790 (m), 644 (w, sh), $636(\mathrm{~m})$.

HRMS (ESI+) for $\mathrm{C}_{21} \mathrm{H}_{34} \mathrm{~N}_{5} \mathrm{O}_{6} \mathrm{ClP}(\mathrm{M}+\mathrm{H})^{+}$: calcd 518.1930, found 518.1928 .

[3R,4R] Diisopropyl 4-amino-1-N-tert-butyloxycarbonylpyrrolidin3-yloxymethylphosphonate 31

Starting from azido derivative $30^{13}(3.12 \mathrm{~g}, 13.67 \mathrm{mmol})$ the same synthetic procedures as for compound 23 were used. The title compound was obtained in $50 \%(2.76 \mathrm{~g}$, $6.8 \mathrm{mmol})$ overall yield.

\section{NMR - (1:1 mixture of amide rotamers)}

${ }^{1} \mathrm{H}$ NMR (500.0 MHz, DMSO- $\left.d_{6}, 25{ }^{\circ} \mathrm{C}\right): 1.222,1.23,1.24(3 \times \mathrm{d}$, $\left.24 \mathrm{H}, J_{\text {vic }}=6.2,\left(\mathrm{CH}_{3}\right)_{2} \mathrm{CH}\right) ; 1.38,1.39\left(2 \times \mathrm{s}, 2 \times 9 \mathrm{H},\left(\mathrm{CH}_{3}\right)_{3} \mathrm{C}\right)$; 3.00 (bd, $\left.2 \mathrm{H}, J_{\text {gem }}=10.7, \mathrm{H}-5 \mathrm{~b}\right) ; 3.23-3.33(\mathrm{~m}, 4 \mathrm{H}, \mathrm{H}-2 \mathrm{~b}, 5 \mathrm{a})$; 3.34 (bm, $2 \mathrm{H}, \mathrm{H}-4)$; 3.44, $3.47\left(2 \times \mathrm{dd}, 2 \times 1 \mathrm{H}, J_{\text {gem }}=12.0\right.$, $\left.J_{2 \mathrm{a}, 3}=4.4, \mathrm{H}-2 \mathrm{a}\right) ; 3.68(\mathrm{bm}, 2 \mathrm{H}, \mathrm{H}-3) ; 3.73-3.82\left(\mathrm{~m}, 4 \mathrm{H}, \mathrm{CH}_{2} \mathrm{P}\right)$; 4.53-4.63 (m, 4H, CH $\left.\left(\mathrm{CH}_{3}\right)_{2}\right)$.

${ }^{13} \mathrm{C}$ NMR (125.7 MHz, DMSO- $\left.d_{6}, 25{ }^{\circ} \mathrm{C}\right): 23.85,23.87$ (d, $\left.J_{\mathrm{C}, \mathrm{P}}=4.4,\left(\mathrm{CH}_{3}\right)_{2} \mathrm{CH}\right) ; 24.01,24.02\left(\mathrm{~d}, J_{\mathrm{C}, \mathrm{P}}=3.6,\left(\mathrm{CH}_{3}\right)_{2} \mathrm{CH}\right)$; 
$28.37\left(\left(\mathrm{CH}_{3}\right)_{3} \mathrm{C}\right) ; 48.94,49.32\left(\mathrm{CH}_{2}-2\right) ; 51.99,52.32\left(\mathrm{CH}_{2}-5\right)$; 53.82, $54.67(\mathrm{CH}-4) ; 63.10,63.23\left(\mathrm{~d}, J_{\mathrm{C}, \mathrm{P}}=165.5, \mathrm{CH}_{2} \mathrm{P}\right)$;

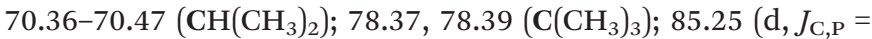
12.5, CH-3); 86.14 (d, $\left.J_{\mathrm{C}, \mathrm{P}}=12.0, \mathrm{CH}-3\right) ; 153.95,153.99$ (CO).

${ }^{31} \mathrm{P}\left\{{ }^{1} \mathrm{H}\right\}$ NMR (202.3 MHz, DMSO- $\left.d_{6}, 25{ }^{\circ} \mathrm{C}\right): 20.24,20.39$.

HRMS (ESI+) for $\mathrm{C}_{16} \mathrm{H}_{33} \mathrm{~N}_{2} \mathrm{O}_{6} \mathrm{PNa}(\mathrm{M}+\mathrm{H}+\mathrm{Na})^{+}$: calcd 403.1968, found 403.1971.

\section{Determination of kinetic constants}

The $K_{\mathrm{i}}$ values for the ANPs were determined using a spectrophotometric method (J. Med. Chem. (2009) 52: 4390) with the concentration of the invariable substrate (guanine) being $60 \mu \mathrm{M}$ and the concentration of the variable substrate (PRib$\mathrm{PP})$ ranging between 20 and $580 \mu \mathrm{M}$. The values were calculated from Hanes plots using the equations for either competitive or non-competitive inhibition.

\section{Docking studies}

The three dimensional structures of 15c, 15d, 16c and 16d were obtained using the PRODRG2 server. $^{24}$ The program GOLD was used for all the docking calculations. ${ }^{22}$ Coordinates for human HGPRT were obtained using chain A of the complex with 2-(phosphonoethoxy)ethyl guanine (PEEG, PDB: 3GGJ) and 2-(phosphonoethoxy)ethyl hypoxanthine (PEEHx, PDB: $3 G G C) .{ }^{21}$ For setting up the protein template, the inhibitor, the water molecules and the magnesium ions were removed from the coordinates. Prior to docking simulations the enzyme was protonated using the GOLD default settings. The active site centre was defined by the coordinates of the phosphorus atom of PEEG or PEEHx when bound to human HGPRT. The search radius for all calculations was $15 \AA$. For each ligand twenty independent docking searches were performed. The GoldScore fitness function (default settings) was used to rank the poses. This algorithm takes into account the H-bonding energy, van der Waals energy and ligand torsion strain.

\section{Acknowledgements}

Support by grants \#13-24880S and \#P207/11/0108 (Czech Science Foundation), National Health and Medical Research Council \#1030353, is gratefully acknowledged.

\section{Notes and references}

1 A. Holý and I. Rosenberg, Collect. Czech. Chem. Commun., 1982, 47, 3447-3463.

2 E. De Clercq, M. Baba, R. Pauwels, J. Balzarini, I. Rosenberg and A. Holý, Antiviral Res., 1987, 8, 261-272.

3 J. Balzarini, L. Naesens, P. Herdewijn, I. Rosenberg, A. Holý, R. Pauwels, M. Baba, D. G. Johns and E. De Clercq, Proc. Natl. Acad. Sci. U. S. A., 1989, 86, 332-336.
4 R. L. Mackman, C. G. Boojamra, V. Prasad, L. Zhang, K. Y. Lin, O. Petrakovsky, D. Babusis, J. Chen, J. Douglas, D. Grant, H. C. Hui, C. U. Kim, D. Y. Markevitch, J. Vela, A. Ray and T. Cihlar, Bioorg. Med. Chem. Lett., 2007, 17, 6785-6789.

5 M. R. Harnden and R. L. Jarvest, Tetrahedron Lett., 1991, 32, 3863-3866.

6 M. R. Harnden, M. J. Jarvest and R. L. Parratt, J. Chem. Soc., Perkin Trans. 1, 1992, 2259-2263.

7 D. R. Adams, A. S. F. Boyd, R. Ferguson, D. S. Grierson and C. Monneret, Nucleosides, Nucleotides Nucleic Acids, 1998, 17, 1053-1075.

8 U. Chiacchio, E. Balestrieri, B. Macchi, D. Iannazzo, A. Piperno, A. Rescifina, R. Romeo, M. Saglimbeni, M. T. Sciortino, V. Valveri, A. Mastino and G. Romeo, J. Med. Chem., 2005, 48, 1389-1394.

9 G. A. Sheikha, P. L. Colla and A. G. Loi, Nucleosides, Nucleotides Nucleic Acids, 2002, 21, 619-635.

10 D. Rejman, P. Kočalka, M. Buděšínský, R. Pohl and I. Rosenberg, Tetrahedron, 2007, 63, 1243-1253.

11 D. Rejman, R. Pohl, P. Kočalka, M. Masojídková and I. Rosenberg, Tetrahedron, 2009, 65(18), 3673-3681.

12 P. Kocalka, D. Rejman, V. Vanek, M. Rinnová, I. Tomecková, S. Králíková, M. Petrová, O. Páv, R. Pohl, M. Budesínský, R. Liboska, Z. Tocík, N. Panova, I. Votruba and I. Rosenberg, Bioorg. Med. Chem. Lett., 2010, 20, 862865.

13 D. Rejman, N. Panova, P. Klener, B. Maswabi, R. Pohl and I. Rosenberg, J. Med. Chem., 2012, 55, 1612-1621.

14 S. Kovačková, M. Dračínský and D. Rejman, Tetrahedron, 2011, 67, 1485-1500.

15 D. Rejman, S. Kovačková, R. Pohl, M. Dračínský, P. Fiedler and I. Rosenberg, Tetrahedron, 2009, 65, 8513-8523.

16 M. Dejmek, H. Hřebabecký, M. Šála, M. Dračínský, E. Procházková, P. Leyssen, J. Neyts, J. Balzarini and R. Nencka, Bioorg. Med. Chem., 2014, 22(11), 2974-2983.

17 C. Altona and M. Sundaralingam, J. Am. Chem. Soc., 1972, 94, 8205-8212.

18 P. Hendrickx and J. Martins, Chem. Central J., 2008, 2, 20.

19 L. Poštová Slavětínská, D. Rejman and R. Pohl, Beilstein J. Org. Chem., 2014, 10(22), 1967-1980.

20 C. Mazzon, C. Rampazzo, M. C. Scaini, L. Gallinaro, A. Karlsson, C. Meier, J. Balzarini, P. Reichard and V. Bianchi, Biochem. Pharmacol., 2003, 66, 471-479.

21 D. T. Keough, D. Hocková, A. Holý, L. M. J. Naesens, T. S. Skinner-Adams, J. de Jersey and L. W. Guddat, J. Med. Chem., 2009, 52, 4391-4399.

22 G. Jones, P. Willett, R. C. Glen, A. R. Leach and R. Taylor, J. Mol. Biol., 1997, 2(67), 727-748.

23 D. T. Keough, T. Skinner-Adams, K. M. Jones, A. L. Ng, I. M. Brereton, L. W. Guddat and J. de Jersey, J. Med. Chem., 2006, 49(25), 7479-7486.

24 A. W. Schüttelkopf and D. M. F. van Aalten, Acta Crystallogr., Sect. D: Biol. Crystallogr., 2004, 1355-1363. 